\title{
PRELIMINARY GEOLOGIC AND HYDROLOGIC EVALUATION OF A SMALL WATERSHED NEAR PLAINS, GEORGIA
}

By David W. Hicks, James B. McConnell, and Loris E. Asmussen

\section{U.S. GEOLOGICAL SURVEY}

Water-Resources Investigations Report 90-4146

Prepared in cooperation with

\section{U.S. DEPARTMENT OF AGRICULTURE}

\section{AGRICULTURAL RESEARCH SERVICE,}

\section{SOUTHEAST WATERSHED RESEARCH LABORATORY}

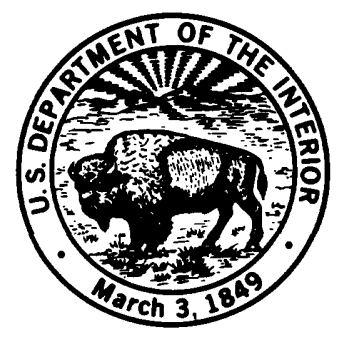

Doraville, Georgia 


\title{
U.S. DEPARTMENT OF THE INTERIOR
}

MANUEL LUJAN, JR., Secretary

\author{
U.S. GEOLOGICÁL SURVEY
}

Dallas L. Peck, Director

For additional information

write to:

District Chief

U.S. Geological Survey

6481 Peachtree Industrial Blvd.

Suite $B$

Doraville, GA 30360
Copies of this report can be purchased from:

U.S. Geological Survey Books and Open-File Reports

Federal Center, Building 810

Box 25425

Denver, CO 80225 


\title{
CONTENTS
}

\author{
Abstract 1 \\ Introduction 2 \\ Purpose and scope 2 \\ Location and description of the study area 2 \\ Land use 2 \\ Monitor-site numbering system 6 \\ Methods 6 \\ Acknowledgments 10 \\ Geology 10 \\ Tuscahoma Formation 10 \\ Tallahatta Formation 10 \\ Undifferentiated residuum and alluvium 14 \\ Hydrology 15 \\ Rainfall 15 \\ Surface-water hydrology 15 \\ Ground-water hydrology 18 \\ Unsaturated zone 18 \\ Saturated zone 18 \\ Water-table fluctuation 19 \\ Rainfall and recharge relation 19 \\ Water Quality 23 \\ Surface-water quality 23 \\ Summary 25 \\ Ground-water quality 25 \\ Selected references 26
}

\section{ILLUSTRATIONS}

Figures 1-5: Maps showing:

1. Location of the study area and physiographic provinces of Georgia 3

2. Location of data collection sites, geologic sections, and study area 4

3. Land use in the Ty Ty Creek tributary watershed, 19865

4. Approximate altitude of the top of the Tallahatta Formation 11

5. Approximate thickness of the unsaturated zone, June 198612

Figure 6. Generalized hydrogeologic section A-A' 13

7. Generalized hydrogeologic section B-B' 14

8. Graph showing average daily rainfall, $1985-86 \quad 16$

9. Hydrograph showing daily stage fluctuations in the unnamed pond, 1985-86 17

10. Water-table altitude and generalized direction of ground-water flow in the Claiborne aquifer, June 198620

11. Hydrographs showing daily water-level fluctuations in wells $10 \mathrm{Q} 038,10 \mathrm{Q} 070,10 \mathrm{Q} 071$ and 10Q072 tapping the Claiborne aquifer, 1985-86 21

12. Map showing water-level change in the Claiborne aquifer, July 1985 to June 198622

\section{TABLES}

Table 1. Index of ground-water monitoring sites 7

2. Agricultural chemicals analyzed in ground water, 1985-86 9

3. Results of chemical and suspended-sediment analyses of rainfall runoff and surface water from the Ty Ty Creek tributary watershed, 1985-86 24

4. Results of chemical analyses of inorganic constituents in ground water, 1985-86 27 


\section{CONVERSION FACTORS}

Multiply inch-pound unit

inch (in.)

foot (ft)

mile (mi)

acre

square mile $\left(\mathrm{mi}^{2}\right)$

$\underline{\text { Volume }}$

gallon (gal)

inch per square foot

(in $/ \mathrm{ft}^{2}$ )

inch per acre

(in/acre)

inch per year

(in/yr)

cubic foot per second

$\left(\mathrm{tt}^{3} / \mathrm{s}\right)$
Area

2.590

By

To obtain metric unit

Length

25.4

0.3048

1.609

0.4047

hectare (ha)

square kilometer $\left(\mathrm{km}^{2}\right)$ millimeter (mm)

meter (m)

kilometer (km)
3.785

273.3

62.76

Flow

25.4

0.02832

liter (L)

millimeter per square meter $\left(\mathrm{mm} / \mathrm{m}^{2}\right)$

millimeter per hectare $(\mathrm{mm} / \mathrm{ha})$

millimeter per year

$(\mathrm{mm} / \mathrm{yr})$

cubic meter per second $\left(\mathrm{m}^{3} / \mathrm{s}\right)$

\section{Sea Level}

In this report, "sea level" refers to the National Geodetic Vertical Datum of 1929--a geodetic datum derived from a general adjustment of the first-order level nets of both the United States and Canada, formerly called "Sea Level Datum of 1929." 


\title{
PRELIMINARY GEOLOGIC AND HYDROLOGIC EVALUATION
}

\author{
OF A SMALL WATERSHED NEAR PLAINS, GEORGIA
}

\author{
By \\ David W. Hicks $1 /$, James B. McConnel1느, and Loris E. Asmussen $2 /$
}

\begin{abstract}
This preliminary evaluation is part of an effort to identify and describe the processes that control the movement and fate of selected fertilizers and pesticides in the surface and subsurface environments in a Coastal Plain area. This report describes the geology and hydrology of a 2.5-square mile (mi²) study area that includes a $1.03 \mathrm{mi}^{2}$ watershed near Plains, Sumter County, Georgia.

The geologic units of interest to this study, in ascending order, are the Tuscahoma Formation, a homogeneous, well sorted, glauconitic, very fine-to-fine, clayey sand; the Tallahatta Formation, a fine-tocoarse, quartz sand; and the undifferentiated residuum and alluvium, alternating and intermittent layers of sand, clayey sand, and clay. Borehole geophysical logs and drill cuttings from 76 test/monitor wells indicate that the unsaturated zone includes the undifferentiated residuum and alluvium and the upper part of the Tallahatta Formation, and ranges in thickness from less than 10 feet ( $\mathrm{ft}$ ) in the toe-slope areas, to more than $50 \mathrm{ft}$ in the interstream (interfluve) areas. The surficial aquifer represents the updip extension of the Claiborne aquifer. Downdip, the Claiborne is a major supplier of ground water to municipal, agricultural, and industrial users. In the study area, this aquifer consists of the lower part of the Tallahatta Formation and ranges in thickness from about 11 to $49 \mathrm{ft}$, and is confined below by the Tuscahoma Formation. Maximum ground-water recharge occurs in the lower part of the midslope areas, and in parts of the toe-slope areas where the overburden is permeable and the land surface is relatively flat.
\end{abstract}

During June 1986, the altitude of the water table ranged from about $466 \mathrm{ft}$ in the northern part of the area to about $434 \mathrm{ft}$ at the southern boundary, and had a nearly uniform slope of about $16.5 \mathrm{ft}$ per mile. Ground-water flow in the watershed generally is from north to south. Seasonal water-level fluctuations in the Claiborne aquifer from July 1985 to June 1986, ranged from 6.4 inches (in.) in the northern part of the area to $21.4 \mathrm{in}$. in the southern part, in response to a total rainfall of $37.6 \mathrm{in}$.

Analyses of surface-water samples indicate that during 1986, runoff from the watershed was low in dissolved constituents, as indicated by specific conductance less than 60 microsiemens per centimeter $(\mu \mathrm{S} / \mathrm{cm})$. Nitrate-nitrogen concentrations ranged from 0.19 to 1.50 milligrams per liter $(\mathrm{mg} / \mathrm{L})$ in runoff samples collected from a cultivated area, and from 0.11 to $0.55 \mathrm{mg} / \mathrm{L}$ at the drain of the unnamed pond, which stores outflow from the watershed.

Ground-water samples collected during 1985-86 also were low in dissolved constituents, as indicated by specific conductance less than $60 \mu \mathrm{S} / \mathrm{cm}$. Nitrate-nitrogen concentrations ranged from less than 0.01 to $3.6 \mathrm{mg} / \mathrm{L}$. Ground-water samples having the highest nitrate-nitrogen concentrations were in water from wells in or near the areas of most rapid recharge. The $\mathrm{pH}$ of ground-water samples ranged from 4.5 to 5.6, which may have important implications to the mobility and the fate of pesticides. Groundwater samples from four wells were analyzed for seven herbicides, three nematicides, and a fungicide. No pesticides were detected.

1/U.S. Geological Survey

2/U.S. Department of Agriculture, Agricultural Research Service 


\section{INTRODUCTION}

Agrichemicals are present in ground water in many parts of the Nation. Because about one-half of the population of the United States and 97 percent of rural households depend on ground water for drinking supplies (Solley and others, 1983), research programs are needed that will evaluate the mechanisms by which land-applied fertilizers and pesticides are transported and degraded in the surface and subsurface environments. The development of practical solutions to prevent the compromise of ground-water resources will come from an understanding of the transport and fate of contaminants in the subsurface and of the processes that take place in that environment.

A cooperative research investigation was initiated in 1984 by the U.S. Geological Survey (USGS) and the U.S. Department of Agriculture, Agricultural Research Service (ARS), to evaluate the effects of agrichemicals and management practices on ground-water quality. The major objective of this investigation is to identify and describe the processes that control the movement and fate of selected fertilizers and pesticides in the surface and subsurface environments. Understanding the hydrology and geology of these environments, as they relate to these processes, is paramount to the successful completion of this research investigation.

\section{Purpose and Scope}

This report provides a preliminary evaluation of the surface and subsurface hydrologic systems in, and near, the Ty Ty Creek tributary watershed near Plains, Ga. (fig. 1). The following geologic and hydrologic factors were evaluated (1) rainfall; (2) lithology, thickness, and water-transport potential of the unsaturated zone; (3) lithology, thickness, hydraulic potential, and water quality within the saturated zone; (4) lithology of the underlying confining zone; and (5) the relation between ground water and surface water in the area.

\section{Location and Description of the Study Area}

The study area is in Sumter County, near Plains, in the Fall Line Hills district of the Georgia Coastal Plain physiographic province (Clark and Zisa, 1976). The study area encompases about $2.5 \mathrm{mi}^{2}$ and includes a $1.03 \mathrm{mi}^{2}$ watershed that is tributary to Ty Ty Creek (figs. 1 and 2). This area was selected because it is representative of typical farming activities in the region and is within the recharge area of the most heavily used ground-water reservoir (Claiborne aquifer) in that area.

Georgia Highway 45 divides the Ty Ty Creek tributary watershed and forms a drainage diversion that redirects runoff from the northern part of the area along the highway right-of-way into Ty Ty Creek. Ty Ty Creek tributary is impounded by the unnamed pond, which covers an area of about 8 acres, and is located near the southern boundary of the study area (fig. 2).

Relatively level interstream areas form surface water divides along the north, east, and west boundaries of the watershed. Headward erosion of Ty Ty Creek tributary and it's tributaries has resulted in entrenched topography. Altitudes range from about $410 \mathrm{ft}$ in the streambed to more than $520 \mathrm{ft}$ in the upland area.

\section{Land Use}

Land use within the watershed is predominantly agricultural; about 398 acres are cleared for rowcrop production (fig. 3). Georgia Highway 45 divides the cropland into a northern section of 111 acres and a southern section of 287 acres. Peanuts, soybeans, corn, wheat, and grain sorghum are the major crops. Forested and grassed areas comprise about 255 acres of the watershed, and a very small percentage of the watershed is residential. 


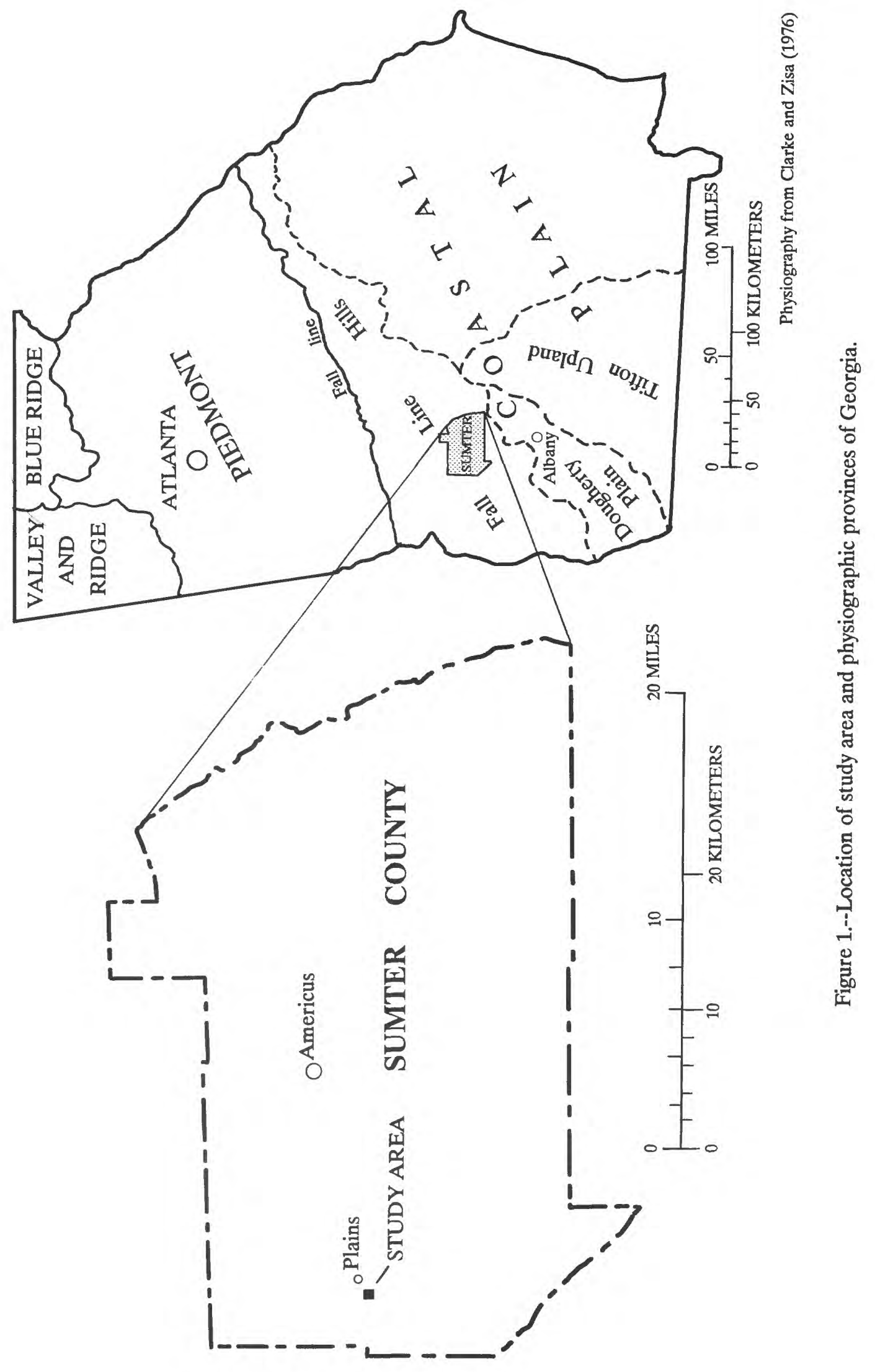




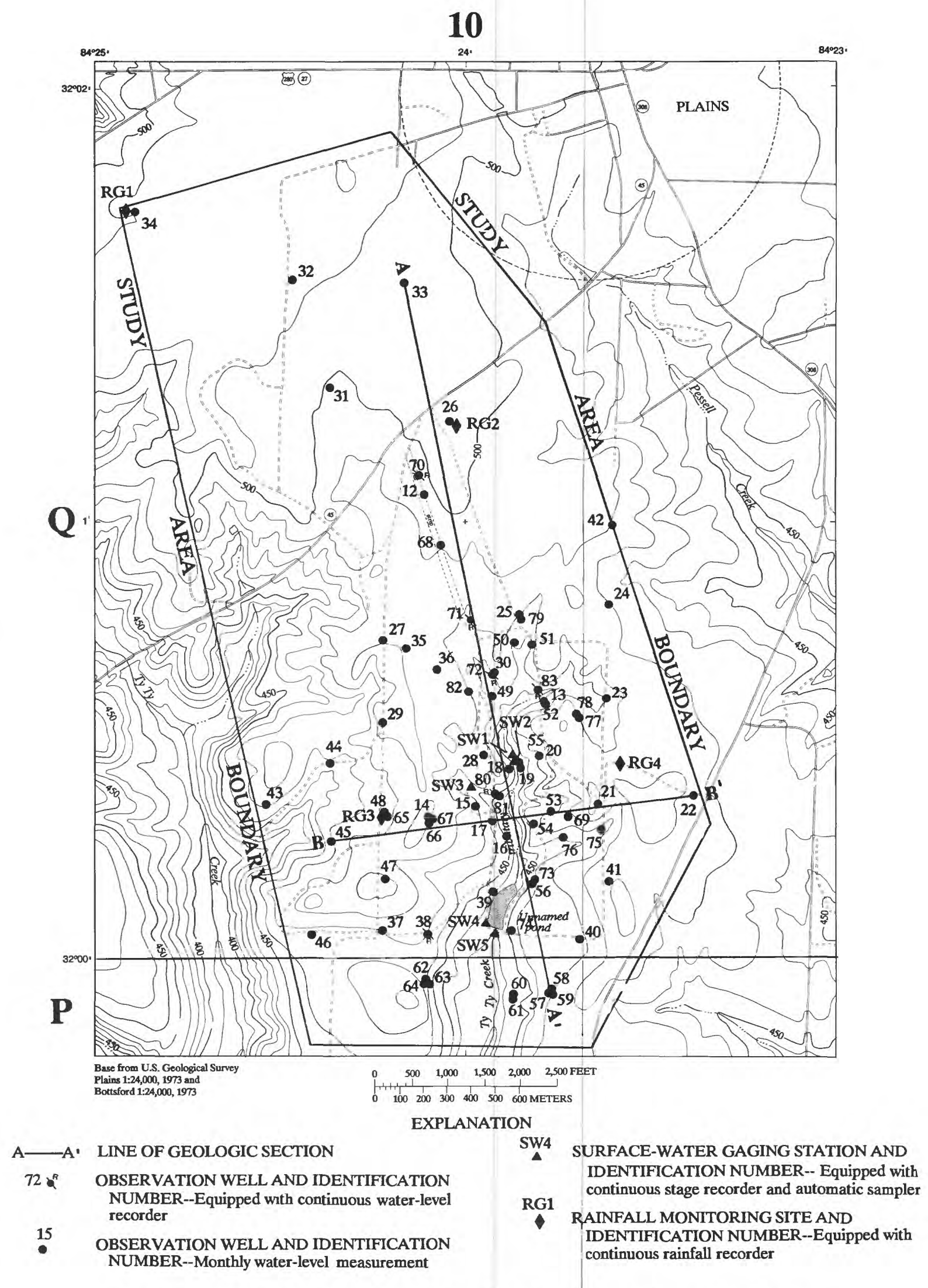

Figure 2.--Location of data-collection sites, line of geologic sections, and study area. 


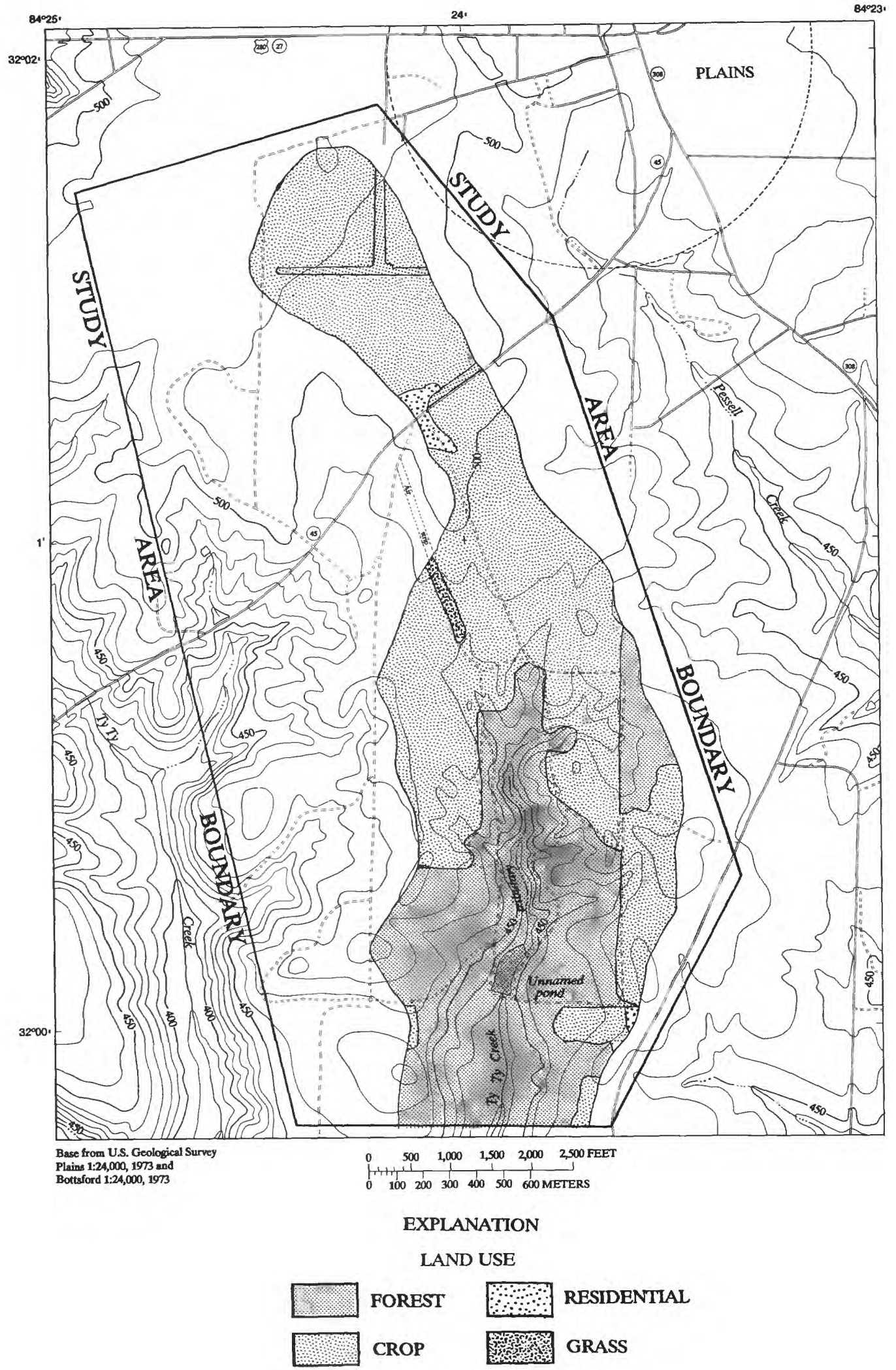

Figure 3.--Land use the Ty Ty Creek tributary watershed, 1986. 


\section{Monitor-Site Numbering System}

Wells in this report are numbered according to a system based on $71 / 2-$ minute quadrangle maps published by the USGS. Each quadrangle in Georgia has been assigned a number and letter designation according to its location. The numbers begin in the southwest corner of the State and increase eastward. The letters begin in the same corner, but progress alphabetically to the north. Wells located in a particular quadrangle are numbered serially. For example, well number 100025 represents well 25 in quadrangle 10Q. For simplification, well numbers used in the text of this report and in several illustrations have been shortened to include only the last two digits of the well number. Surface-water sites are identified in this report by the prefix "SW" and a number. Thus, site SW-1 would correspond to surface-water site 1.

Rainfall-monitor sites are indentified by the prefix "RG" and a number. Thus, RG-1 would represent rainfall-monitor site 1.

\section{Methods}

The USGS and the ARS jointly drilled 72 test/monitor wells and four wells dedicated to microbial sampling in the study area (fig. 2 and table 1.). Each well taps the saturated zone. Borehole geophysical logs were made in the wells to improve an understanding of the hydrogeologic framework. Auger samples were described in the field for each well, and continuous core samples were collected in two wells from land surface to a depth of about $84 \mathrm{ft}$. Polyvinylchloride (PVC) casing and slotted screen were installed in the wells. Each well was developed by bailing, then by air lifting, using compressed air injected through a small-diameter pipe. Continuous water-level recorders were installed on five wells, and water levels were measured monthly in 67 wells.

Soil series encountered in eight pits throughout the basin that were excavated to a depth of about $10 \mathrm{ft}$ were described by soil scientists from the U.S. Department of Agriculture, Soil Conservation Service (SCS). Soil samples were collected from each horizon exposed in the pits and shipped to the SCS laboratory, Lincoln, Nebr., for analyses. The samples were analyzed for particle-size distribution, bulk density, water retention, ion-exchange capacity, acid data, mineralogy, clay mineralogy, and soil aggregation determinations.

Rainfall collectors and recorders were installed at four sites in the area to determine total rainfall and rainfall variability, as well as to evaluate the relations among rainfall, runoff, and recharge. Monitoring equipment was installed to measure runoff ( 3 sites), pond stage ( 1 site), and pond discharge ( 1 site). Aluminum access tubes were installed at three sites to collect soil-moisture data using a neutron resistance probe. These data were correlated with rainfall data to evaluate the rainfall and infiltration relation.

Automated surface-water samplers were installed and instrumented at four sites to collect daily composite samples at the unnamed pond discharge site and timed-event samples were collected at the three runoff sites (fig. 2). Runoff samples were collected to evaluate chemical and sediment transport.

Ground-water quality in the study area was determined from samples collected from the network of wells established for water-level monitoring. Samples were collected from 66 PVC-cased wells at least once, and as many as seven times, between August 1985 and June 1986. Field determinations were made for water temperature, specific conductance, $\mathrm{pH}$, and alkalinity. Samples were analyzed in the ARS laboratory, Tifton, Ga., for selected inorganic constituents. 
Table 1.--Index of ground-water monitoring sites

[S, screened]

\begin{tabular}{|c|c|c|c|c|c|c|c|c|}
\hline $\begin{array}{l}\text { Well } \\
\text { number }\end{array}$ & Latitude & Longitude & $\begin{array}{c}\text { Altitude of } \\
\text { land surface } \\
\text { (feet) }\end{array}$ & $\begin{array}{l}\text { Well } \\
\text { depth } \\
\text { (feet) }\end{array}$ & $\begin{array}{l}\text { Casing } \\
\text { diameter } \\
\text { (inches) }\end{array}$ & $\begin{array}{c}\text { Top } \\
\text { of } \\
\text { opening } \\
\text { (feet) }\end{array}$ & $\begin{array}{l}\text { Bottom } \\
\text { of } \\
\text { opening } \\
\text { (feet) }\end{array}$ & $\begin{array}{c}\text { Type } \\
\text { of } \\
\text { opening }\end{array}$ \\
\hline $10 Q 012$ & $32^{\circ} 01^{\prime} 05^{\prime \prime}$ & $84^{\circ} 24^{\prime} 08^{\prime \prime}$ & 499.00 & 42 & 2 & 38 & 42 & $s$ \\
\hline $10 \mathrm{Q} 013$ & $32^{\circ} 00^{\prime} 34^{\prime \prime}$ & $84^{\circ} 23^{\prime} 47^{\prime \prime}$ & 469.13 & 54 & 2 & 30 & 33 & S \\
\hline $10 \mathrm{Q} 014$ & $32^{\circ} 00^{\prime} 19^{\prime \prime}$ & $84^{\circ} 24^{\prime} 07^{\prime \prime}$ & 489.40 & 73 & 2 & 66 & 71 & $s$ \\
\hline 100015 & $32^{\circ} 00^{\prime} 20^{\prime \prime}$ & $84^{\circ} 23^{\prime} 58^{\prime \prime}$ & 473.66 & 48 & 2 & 43 & 48 & s \\
\hline $10 \mathrm{Q} 016$ & $32^{\circ} 00^{\prime} 15^{\prime \prime}$ & $84^{\circ} 23^{\prime} 54^{\prime \prime}$ & 452.18 & 17 & 2 & 12 & 17 & S \\
\hline $10 Q 017$ & $32^{\circ} 00^{\prime} 19^{\prime \prime}$ & $84^{\circ} 23^{\prime} 55^{\prime \prime}$ & 461.14 & 40 & 2 & 34 & 39 & s \\
\hline 100018 & $32^{\circ} 00^{\prime} 28^{\prime \prime}$ & $84^{\circ} 23^{\prime} 54^{\prime \prime}$ & 458.60 & 45 & 2 & 40 & 45 & s \\
\hline $10 Q 019$ & $32^{\circ} 00^{\prime} 28^{\prime \prime}$ & $84^{\circ} 23^{\prime} 53^{\prime \prime}$ & 450.15 & 29 & 2 & 25 & 28 & $s$ \\
\hline $10 Q 020$ & $32^{\circ} 00^{\prime} 29^{\prime \prime}$ & $84^{\circ} 23^{\prime} 49^{\prime \prime}$ & 467.74 & 44 & 2 & 37 & 40 & $s$ \\
\hline 100021 & $32^{\circ} 00^{\prime} 21^{\prime \prime}$ & $84^{\circ} 23^{\prime} 39^{\prime \prime}$ & 486.24 & 80 & 2 & 66 & 70 & s \\
\hline $10 \mathrm{Q} 022$ & $32^{\circ} 00^{\prime} 22^{\prime \prime}$ & $84^{\circ} 23^{\prime} 23^{\prime \prime}$ & 483.55 & 80 & 2 & 75 & 80 & $s$ \\
\hline 100023 & $32^{\circ} 00^{\prime} 34^{\prime \prime}$ & $84^{\circ} 23^{\prime} 38^{\prime \prime}$ & 473.81 & 40 & 2 & 36 & 40 & s \\
\hline 100024 & $32^{\circ} 00^{\prime} 46^{\prime \prime}$ & $84^{\circ} 23^{\prime \prime} 37^{\prime \prime}$ & 488.74 & 50 & 2 & 46 & 50 & s \\
\hline $10 Q 025$ & $32^{\circ} 00^{\prime} 47^{\prime \prime}$ & $84^{\circ} 23^{\prime} 52^{\prime \prime}$ & 483.05 & 53 & 2 & 45 & 49 & $s$ \\
\hline 100026 & $32^{\circ} 01^{\prime} 15^{\prime \prime}$ & $84^{\circ} 24^{\prime} 03^{\prime \prime}$ & 499.67 & 70 & 2 & 66 & 70 & s \\
\hline $10 \mathrm{Q} 027$ & $32^{\circ} 00^{\prime} 44^{\prime \prime}$ & $84^{\circ} 24^{\prime} 14^{\prime \prime}$ & 488.85 & 65 & 2 & 59 & 63 & S \\
\hline 100028 & $32^{\circ} 00^{\prime} 31^{\prime \prime}$ & $84^{\circ} 23^{\prime} 57^{\prime \prime}$ & 476.58 & 40 & 2 & 37 & 40 & $s$ \\
\hline 100029 & $32^{\circ} 00^{\prime} 33^{\prime \prime}$ & $84^{\circ} 23^{\prime} 13^{\prime \prime}$ & 493.75 & 60 & 2 & 53 & 57 & s \\
\hline $10 \mathrm{Q} 030$ & $32^{\circ} 00^{\prime} 38^{\prime \prime}$ & $84^{\circ} 23^{\prime} 55^{\prime \prime}$ & 472.45 & 37 & 2 & 34 & 37 & s \\
\hline 100031 & $32^{\circ} 01^{\prime} 18^{\prime \prime}$ & $84^{\circ} 24^{\prime} 23^{\prime \prime}$ & 499.46 & 52 & 2 & 48 & 52 & $S$ \\
\hline 100032 & $32^{\circ} 01^{\prime} 33^{\prime \prime}$ & $84^{\circ} 24^{\prime} 27^{\prime \prime}$ & 511.21 & 63 & 2 & 59 & 63 & s \\
\hline $10 Q 033$ & $32^{\circ} 01^{\prime} 33^{\prime \prime}$ & $84^{\circ} 24^{\prime} 10^{\prime \prime}$ & 505.00 & 59 & 2 & 55 & 59 & S \\
\hline 100034 & $32^{\circ} 01^{\prime} 43^{\prime \prime}$ & $84^{\circ} 24^{\prime} 52^{\prime \prime}$ & 515.96 & 63 & 2 & 56 & 60 & s \\
\hline $10 Q 035$ & $32^{\circ} 00^{\prime} 42^{\prime \prime}$ & $84^{\circ} 24^{\prime} 08^{\prime \prime}$ & 483.30 & 52 & 2 & 48 & 52 & s \\
\hline $10 Q 036$ & $32^{\circ} 00^{\prime} 40^{\prime \prime}$ & $84^{\circ} 24^{\prime} 04^{\prime \prime}$ & 484.50 & 48 & 2 & 44 & 48 & s \\
\hline $10 Q 037$ & $32^{\circ} 00^{\prime} 04^{\prime \prime}$ & $84^{\circ} 24^{\prime} 13^{\prime \prime}$ & 466.36 & 48 & 2 & 44 & 48 & S \\
\hline $10 \mathrm{Q} 038$ & $32^{\circ} 00^{\prime} 03^{\prime \prime}$ & $84^{\circ} 24^{\prime} 05^{\prime \prime}$ & 467.92 & 43 & 2 & 39 & 43 & s \\
\hline 100039 & $32^{\circ} 00^{\prime} 11^{\prime \prime}$ & $84^{\circ} 23^{\prime} 57^{\prime \prime}$ & 444.98 & 23 & 2 & 20 & 23 & s \\
\hline $10 \mathrm{Q} 040$ & $32^{\circ} 00^{\prime} 02^{\prime \prime}$ & $84^{\circ} 23^{\prime} 43^{\prime \prime}$ & 468.06 & 48 & 2 & 44 & 48 & S \\
\hline $10 Q 041$ & $32^{\circ} 00^{\prime} 11^{\prime \prime}$ & $84^{\circ} 23^{\prime} 38^{\prime \prime}$ & 484.68 & 63 & 2 & 59 & 63 & s \\
\hline 100042 & $32^{\circ} 01^{\prime} 00^{\prime \prime}$ & $84^{\circ} 23^{\prime} 37^{\prime \prime}$ & 493.28 & 53 & 2 & 49 & 53 & S \\
\hline 100043 & $32^{\circ} 00^{\prime} 22^{\prime \prime}$ & $84^{\circ} 24^{\prime} 32^{\prime \prime}$ & 470.00 & 58 & 2 & 53 & 58 & $s$ \\
\hline 100044 & $32^{\circ} 00^{\prime} 27^{\prime \prime}$ & $84^{\circ} 24^{\prime} 21^{\prime \prime}$ & 468.38 & 46 & 2 & 41 & 46 & s \\
\hline $10 \mathrm{Q} 045$ & $32^{\circ} 00^{\prime} 17^{\prime \prime}$ & $84^{\circ} 24^{\prime} 00^{\prime \prime}$ & 467.67 & 41 & 2 & 36 & 41 & S \\
\hline 100046 & $32^{\circ} 00^{\prime} 03^{\prime \prime}$ & $84^{\circ} 24^{\prime} 25^{\prime \prime}$ & 469.49 & 47 & 2 & 42 & 47 & s \\
\hline $10 Q 047$ & $32^{\circ} 00^{\prime} 10^{\prime \prime}$ & $84^{\circ} 24^{\prime} 13^{\prime \prime}$ & 488.68 & 62 & 2 & 57 & 62 & S \\
\hline $10 \mathrm{Q} 048$ & $32^{\circ} 00^{\prime} 20^{\prime \prime}$ & $84^{\circ} 24^{\prime} 14^{\prime \prime}$ & 473.42 & 47 & 2 & 42 & 47 & $s$ \\
\hline 100049 & $32^{\circ} 00^{\prime} 36^{\prime \prime}$ & $84^{\circ} 23^{\prime} 56^{\prime \prime}$ & 475.43 & 44 & 2 & 39 & 44 & s \\
\hline $10 \mathrm{Q} 050$ & $32^{\circ} 00^{\prime} 42^{\prime \prime}$ & $84^{\circ} 23^{\prime} 53^{\prime \prime}$ & 477.53 & 48 & 2 & 43 & 48 & S \\
\hline $10 \mathrm{Q} 051$ & $32^{\circ} 00^{\prime} 42^{\prime \prime}$ & $84^{\circ} 23^{\prime} 49^{\prime \prime}$ & 477.93 & 58 & 2 & 53 & 58 & $\mathrm{~s}$ \\
\hline 100052 & $32^{\circ} 00^{\prime} 34^{\prime \prime}$ & $84^{\circ} 23^{\prime} 47^{\prime \prime}$ & 469.00 & 52 & 2 & 47 & 52 & $\mathrm{~S}$ \\
\hline $10 \mathrm{Q} 053$ & $32^{\circ} 00^{\prime} 18^{\prime \prime}$ & $84^{\circ} 23^{\prime} 48^{\prime \prime}$ & 468.09 & 58 & 2 & 53 & 58 & S \\
\hline 100054 & $32^{\circ} 00^{\prime} 16^{\prime \prime}$ & $84^{\circ} 23^{\prime} 50^{\prime \prime}$ & 458.02 & 33 & 2 & 28 & 33 & $s$ \\
\hline 100055 & $32^{\circ} 00^{\prime} 28^{\prime \prime}$ & $84^{\circ} 23^{\prime} 53^{\prime \prime}$ & 450.26 & 46 & 2 & 41 & 46 & S \\
\hline 100056 & $32^{\circ} 00^{\prime} 10^{\prime \prime}$ & $84^{\circ} 23^{\prime} 50^{\prime \prime}$ & 452.95 & 40 & 2 & 35 & 40 & $\vec{s}$ \\
\hline 10P057 & $31^{\circ} 59^{\prime} 56^{\prime \prime}$ & $84^{\circ} 23^{\prime} 47^{\prime \prime}$ & 462.06 & 45 & 2 & 41 & 45 & s \\
\hline 10P058 & $31^{\circ} 59^{\prime} 56^{\prime \prime}$ & $84^{\circ} 23^{\prime} 47^{\prime \prime}$ & 462.09 & 45 & 2 & 41 & 45 & s \\
\hline
\end{tabular}


Table 1.--Index of ground-water monitoring sites--Continued

$[\mathrm{S}$, screened]

\begin{tabular}{|c|c|c|c|c|c|c|c|c|}
\hline $\begin{array}{c}\text { Well } \\
\text { number }\end{array}$ & Latitude & Longitude & $\begin{array}{l}\text { Altitude of } \\
\text { land surface } \\
\text { (feet) }\end{array}$ & $\begin{array}{l}\text { Well } \\
\text { depth } \\
\text { (feet) }\end{array}$ & $\begin{array}{l}\text { Casing } \\
\text { diameter } \\
\text { (inches) }\end{array}$ & $\begin{array}{c}\text { Top } \\
\text { of } \\
\text { opening } \\
\text { (feet) }\end{array}$ & $\begin{array}{c}\text { Bottom } \\
\text { of } \\
\text { opening } \\
\text { (feet) }\end{array}$ & $\begin{array}{c}\text { Type } \\
\text { of } \\
\text { opening }\end{array}$ \\
\hline $10 \mathrm{P} 059$ & $31^{\circ} 59^{\prime} 56^{\prime \prime}$ & $84^{\circ} 23^{\prime} 47^{\prime \prime}$ & 462.17 & 32 & 2 & 27 & 32 & $s$ \\
\hline $10 \mathrm{P} 060$ & $31^{\circ} 59^{\prime} 55^{\prime \prime}$ & $84^{\circ} 23^{\prime} 53^{\prime \prime}$ & 440.63 & 64 & 2 & 39 & 44 & $s$ \\
\hline 10P061 & $31^{\circ} 59^{\prime} 55^{\prime \prime}$ & $84^{\circ} 23^{\prime} 53^{\prime \prime}$ & 440.46 & 24 & 2 & 19 & 24 & $s$ \\
\hline 10P062 & $31^{\circ} 59^{\prime} 55^{\prime \prime}$ & $84^{\circ} 24^{\prime} 07^{\prime \prime}$ & 464.66 & 82 & 2 & 77 & 82 & S \\
\hline 10P063 & $31^{\circ} 59^{\prime} 55^{\prime \prime}$ & $84^{\circ} 24^{\prime} 07^{\prime \prime}$ & 464.56 & 56 & 2 & 31 & 36 & $s$ \\
\hline $10 \mathrm{P} 064$ & $31^{\circ} 59^{\prime} 55^{\prime \prime}$ & $84^{\circ} 24^{\prime} 07^{\prime \prime}$ & 464.50 & 56 & 2 & 51 & 56 & $S$ \\
\hline 100065 & $32^{\circ} 00^{\prime} 19^{\prime \prime}$ & $84^{\circ} 24^{\prime} 04^{\prime \prime}$ & 473.77 & 65 & 2 & 35 & 40 & $S$ \\
\hline 100066 & $32^{\circ} 00^{\prime} 19^{\prime \prime}$ & $84^{\circ} 24^{\prime} 07^{\prime \prime}$ & 489.32 & 55 & 2 & 50 & 55 & $S$ \\
\hline 100067 & $32^{\circ} 00^{\prime} 19^{\prime \prime}$ & $84^{\circ} 24^{\prime} 07^{\prime \prime}$ & 490.18 & 65 & 2 & 60 & 65 & s \\
\hline $10 \mathrm{Q} 068$ & $32^{\circ} 01^{\prime} 00^{\prime \prime}$ & $84^{\circ} 24^{\prime} 06^{\prime \prime}$ & 493.20 & 84 & 2 & 45 & 50 & $S$ \\
\hline 100069 & $32^{\circ} 00^{\prime} 19^{\prime \prime}$ & $84^{\circ} 23^{\prime} 45^{\prime \prime}$ & 473.16 & 68 & 2 & 40 & 45 & $\mathrm{~S}$ \\
\hline 100070 & $32^{\circ} 01^{\prime} 07^{\prime \prime}$ & $84^{\circ} 24^{\prime} 08^{\prime \prime}$ & 495.64 & 70 & 4 & 48 & 58 & S \\
\hline $10 \mathrm{Q} 071$ & $32^{\circ} 00^{\prime} 48^{\prime \prime}$ & $84^{\circ} 24^{\prime} 01^{\prime \prime}$ & 485.39 & 60 & 4 & 45 & 55 & $S$ \\
\hline $10 \mathrm{Q} 072$ & $32^{\circ} 00^{\prime} 39^{\prime \prime}$ & $84^{\circ} 23^{\prime} 56^{\prime \prime}$ & 471.97 & 50 & 4 & 38 & 48 & S \\
\hline 100073 & $32^{\circ} 00^{\prime} 10^{\prime \prime}$ & $84^{\circ} 23^{\prime} 50^{\prime \prime \prime}$ & 453.00 & 21 & 2 & 16 & 21 & $S$ \\
\hline $10 \mathrm{Q} 074$ & $32^{\circ} 00^{\prime} 03^{\prime \prime}$ & $84^{\circ} 23^{\prime} 53^{\prime \prime}$ & 454.30 & 62 & 2 & 57 & 62 & S \\
\hline 100075 & $32^{\circ} 00^{\prime} 18^{\prime \prime}$ & $84^{\circ} 23^{\prime} 38^{\prime \prime}$ & 471.85 & 77 & 2 & 67 & 72 & $S$ \\
\hline $10 \mathrm{Q} 076$ & $32^{\circ} 00^{\prime} 16^{\prime \prime}$ & $84^{\circ} 23^{\prime} 46^{\prime \prime}$ & 459.00 & 62 & 2 & 57 & 62 & $S$ \\
\hline $10 \mathrm{Q} 077$ & $32^{\circ} 00^{\prime} 35^{\prime \prime}$ & $84^{\circ} 23^{\prime} 42^{\prime \prime}$ & 482.00 & 76 & 2 & 56 & 61 & $\mathbf{S}$ \\
\hline 100078 & $32^{\circ} 00^{\prime} 35^{\prime \prime}$ & $84^{\circ} 23^{\prime} 42^{\prime \prime}$ & 482.00 & 47 & 2 & 42 & 47 & $\mathrm{~s}$ \\
\hline 100079 & $32^{\circ} 00^{\prime} 47^{\prime \prime}$ & $84^{\circ} 23^{\prime} 52^{\prime \prime}$ & 483.00 & 40 & 2 & 35 & 40 & $\mathrm{~s}$ \\
\hline $10 \mathrm{Q} 080$ & $32^{\circ} 00^{\prime} 23^{\prime \prime}$ & $84^{\circ} 23^{\prime} 54^{\prime \prime}$ & 459.75 & 25 & 4 & 20 & 25 & $S$ \\
\hline $10 \mathrm{Q} 081$ & $32^{\circ} 00^{\prime} 23^{\prime \prime}$ & $84^{\circ} 23^{\prime} 54^{\prime \prime}$ & 459.49 & 43 & 2 & 38 & 43 & S \\
\hline $10 \mathrm{Q} 082$ & $32^{\circ} 00^{\prime} 37^{\prime \prime}$ & $84^{\circ} 24^{\prime} 00^{\prime \prime}$ & 481.00 & 42 & 2 & 37 & 42 & S \\
\hline $10 \mathrm{Q} 083$ & $32^{\circ} 00^{\prime} 37^{\prime \prime}$ & $84^{\circ} 23^{\prime} 49^{\prime \prime}$ & 465.00 & 32 & 4 & 27 & 32 & $\mathrm{~S}$ \\
\hline
\end{tabular}

Initial water-quality data were collected from selected wells in August, September, and October 1985 , after the wells had been cleaned by bailing but before development was completed by air lifting. After the test/monitor well network was developed, sampling for inorganic constituents resumed in March 1986. From March to June, samples were collected once a month from selected wells.

In May 1986, samples were collected for pesticide analyses from four wells $(32,38,70$, and 72$)$. The samples were analyzed for seven herbicides (alachlor, atrazine, cyanazine, metolachlor, metribuzine, pendimethalin, and sulfometuron methyl), three nematicides (fenamiphos, aldicarb, aldicarb sulfone), and a fungicide (metalaxyl) (fig. 2 and table 2).

Quality-assurance measures included the development of wells before sampling and the analysis of replicate samples, field blanks, and field-spiked samples. Samples were stored on ice until time of analysis, which was about 3 days after collection. 
Table 2.--Agricultural chemicals analyzed in ground water, 1983-86

[*, manufacturer's trade name; $\mathrm{P}$, pesticide; $\mathrm{mg} / \mathrm{L}$, milligrams per liter; toxicity is expressed as a dose which is lethal to 50 percent of the rats tested, in milligrams per kilogram of body weight as $\mathrm{LD}_{50}$-adult rat, $\mathrm{mg} / \mathrm{Kg}$;

${ }^{\circ} \mathrm{C}$, degrees Celsius; <, less than; . >, greater than; --, no data.

Source: Farm Chemicals Handbook and The Merck Index]

\begin{tabular}{|c|c|c|c|c|c|}
\hline Name & Chemical name & $\begin{array}{l}\text { Molecular } \\
\text { weight }\end{array}$ & Use & $\begin{array}{l}\text { Solubility } \\
\text { in water } \\
\text { (mg/L) }\end{array}$ & $\begin{array}{l}\text { Toxicity } \\
\left(\mathrm{LD}_{50^{-}} \text {adult }\right. \\
\text { rat, } \mathrm{mg} / \mathrm{Kg})\end{array}$ \\
\hline $\begin{array}{l}\text { Metribuzin (Lexone*, } \\
\text { Sencor*), P }\end{array}$ & $\begin{array}{l}\text { 4-Amino-6-(1,1-dimethylethyl)-3- } \\
\text { (methylio)-1,2,4-triazin-5(4H)-one }\end{array}$ & 214 & herbicide & 1,200 & 2,200 \\
\hline $\begin{array}{l}\text { Pendimethalin (Prowl*, } \\
\text { Stomp*), P }\end{array}$ & $\begin{array}{l}\mathrm{N} \text {-(1-Ethylpropyl)-3,4-dimethyl-2,6- } \\
\text { dinitrobenzenamine }\end{array}$ & 281 & herbicide & 0.3 at $20^{\circ} \mathrm{C}$ & 1,250 \\
\hline $\begin{array}{l}\text { Metolachlor (Dual*, } \\
\text { Bicap*), P }\end{array}$ & $\begin{array}{l}\text { 2-Chloro-N-(2-ethyl-6-methylphenyl)- } \\
\mathrm{N} \text {-(2-methoxy-1-methylethyl) } \\
\text { acetamide }\end{array}$ & 284 & herbicide & 530 at $20^{\circ} \mathrm{C}$ & 2,780 \\
\hline $\begin{array}{l}\text { Alachlor (Alanex*, } \\
\text { Lasso*), P }\end{array}$ & $\begin{array}{l}\text { 2-Chloro-2'-6'-diethyl-N-(methoxy- } \\
\text { methyl)-acetanilide }\end{array}$ & 270 & herbicide & 140 & 1,200 \\
\hline Aldicarb (Temik*) & $\begin{array}{l}\text { 2-Methyl-2-(methylthio)propanal } \\
\text { O- }[(\text { methylamino }) \text { carbonyl }] \text { oxime }\end{array}$ & 190 & $\begin{array}{l}\text { insecticide, } \\
\text { nematicide, } \\
\text { acaricide }\end{array}$ & 6,000 & 0.9 \\
\hline $\begin{array}{l}\text { Aldoxycarb (Standak* } \\
\text { aldicarb sulfone) }\end{array}$ & $\begin{array}{l}2 \text { Methyl-2-(methylsulfonyl)propanal } \\
\text { O-[(methylamino)carbonyl] oxime }\end{array}$ & - & $\begin{array}{l}\text { nematicide, } \\
\text { insecticide }\end{array}$ & - & 26.8 \\
\hline $\begin{array}{l}\text { Metalaxyl (Ridomil*, } \\
\text { Subdue) }\end{array}$ & $\begin{array}{l}\mathrm{N}-(2,6-D i m e t h y l p h e n y l)-\mathrm{N}-(\text { methoxy- } \\
\text { acetyl)-DL-alanine methyl ester }\end{array}$ & 279 & fungicide & 7,100 & $>3,100$ \\
\hline $\begin{array}{l}\text { Atrazine (AAtrex*, } \\
\text { Atred*) }\end{array}$ & $\begin{array}{l}\text { 6-Chloro-N-ethyl-N'-(1-methylethyl)- } \\
\text { 1,3,5-triazine-2,4-diamine }\end{array}$ & 216 & herbicide & 70 & 1,780 \\
\hline Cyanazine (Bladex*) & $\begin{array}{l}\text { 2-[[4-Chloro-6-(ethylamino)-1,3,5- } \\
\text { triazin-2-yl]amino]-2-methyl- } \\
\text { propanenitrile }\end{array}$ & 241 & herbicide & 171 & $\begin{array}{r}182 \\
\text { to } \\
320\end{array}$ \\
\hline Fenamiphos (Nemacur*) & $\begin{array}{l}\text { Ethyl 3-methyl-4-(methylthio)phenyl } \\
\text { (1-methylethyl)phosphoramidate }\end{array}$ & 303 & nematicide & 400 & $\begin{array}{r}8.1 \\
\text { to } \\
9.6\end{array}$ \\
\hline $\begin{array}{l}\text { Sulfometuron methyl } \\
\left(\text { Oust* }^{*}\right)\end{array}$ & $\begin{array}{l}\text { Methyl 2[[I[(4,6-dimethyl-2- } \\
\text { pyrimidinyl)amino]carbonyl]amino] } \\
\text { sulfonyl]benzoate }\end{array}$ & 363 & herbicide & $\begin{array}{r}10 \text { at } \mathrm{pH} 5 \\
300 \text { at } \mathrm{pH} 7\end{array}$ & $>5,000$ \\
\hline
\end{tabular}




\section{Acknowledgments}

Special appreciation is extended to Horizon Farms, Inc., for allowing wells to be drilled and monitoring equipment to be installed on their property near Plains. The USGS and ARS wish to thank James Dozier and Walter Dozier for their cooperation and for providing valuable historic land-use information. The courtesies and help extended by Bob Moss and his staff at the University of Georgia, Coastal Plains Experiment Station at Plains, are sincerely appreciated. The authors wish to acknowledge the significant soil-mapping contribution by SCS personnel, Athens, and additional soil work conducted by Henry F. "Jack" Perkins, formerly with the University of Georgia, Department of Agronomy, Athens.

\section{GEOLOGY}

The Coastal Plain sediments underlying the study area consist of alternating beds of limestone, sand, silt, shale, and clay that extend to a depth of at least $5,000 \mathrm{ft}$, and dip to the southeast by as much as $25 \mathrm{ft} / \mathrm{mi}$, progressively thickening in that direction (Hicks and others, 1981). The uppermost geologic formations of these sediments are discussed in this report, in ascending order; they are the Tuscahoma Formation of late Paleocene age, the Tallahatta Formation of middle Eocene age, and the undifferentiated residuum and alluvium of Quatenary age (figs. 4, 5, 6, and 7).

\section{Tuscahoma Formation}

The Tuscahoma Formation is divided into two lithologic units. The lower unit was described by Herrick (1961) as a light-brown to yellowish-brown, medium sand to granule gravel containing abundant glauconite and thin clay laminae. The upper unit consists of pale yellowish-brown and light-gray very fineto-fine, moderately sorted, carbonaceous, clayey sand. Dark minerals and pockets containing abundant glauconite are common. Glauconite is randomly dispersed and is less abundant in the upper unit than in the lower unit. The upper unit is further subdivided as a result of an abrupt color change from olive gray (in the lower part) to pale-yellowish brown (in the upper part). This lithologic and color sequence is common within the Tuscahoma Formation in the Plains area, and is attributed to deep weathering and leaching (T.G. Gibson, USGS, oral commun., 1986).

Because monitoring wells do not fully penetrate the Tuscahoma Formation in the study area, the Formation thickness has not been determined. Owen (1963) reported the Formation to be about $70 \mathrm{ft}$ thick outside the study area in southwestern Sumter County. An irrigation well at the Coastal Plain Experiment Station at Plains (about 1 mi northeast of the study area) penetrated $64 \mathrm{ft}$ of the Tuscahoma Formation. Thus, it is likely that the Tuscahoma is greater than $60 \mathrm{ft}$ thick in the study area. The Tuscahoma Formation dips to the southeast at a rate of approximately $22 \mathrm{ft} / \mathrm{mi}$.

\section{Tallahatta Formation}

The Tallahatta Formation overlies the Tuscahoma Formation and, herein, is divided into two lithologic units. The lower unit varies in color from pale yellowish-brown, to pale orange, to lavender, and consists of very fine to gravelly, poorly sorted, clear to milky quartz sand. Clay laminae and cross bedding are common. The upper unit consists of pale yellowish-orange to grayish-brown, fine to medium, poorly sorted, cross-bedded, clear to milky quartz sand.

The thickness of the Tallahatta Formation differs areally and ranges from 18 to $49 \mathrm{ft}$. The Formation becomes progressively thinner from the interstream to the toe-slope areas and is thinnest beneath the bed of Ty Ty Creek tributary. In places, the upper surface is exposed as a result of erosion (figs. 4, 6, and 7). 


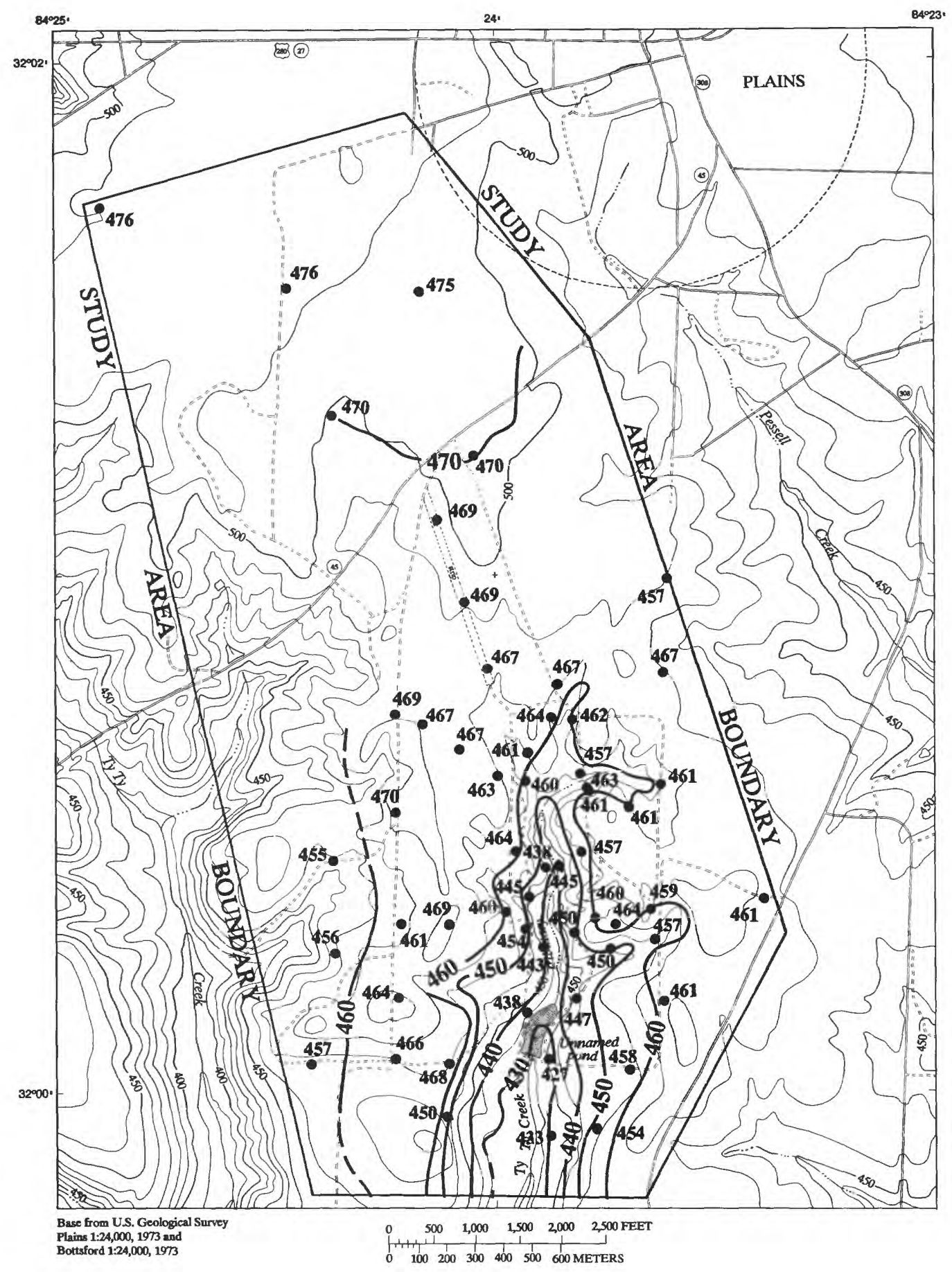

EXPLANATION

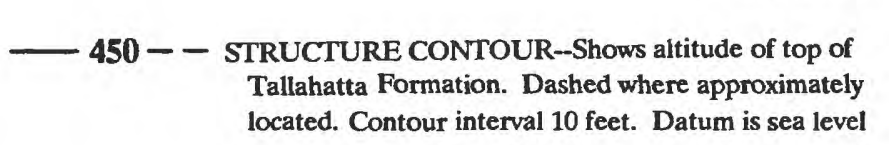

443

- WELL-Number is altitude of top of the Tallahatta Formation, in feet

Figure 4.--Approximate altitude of the top of the Tallahatta Formation. 


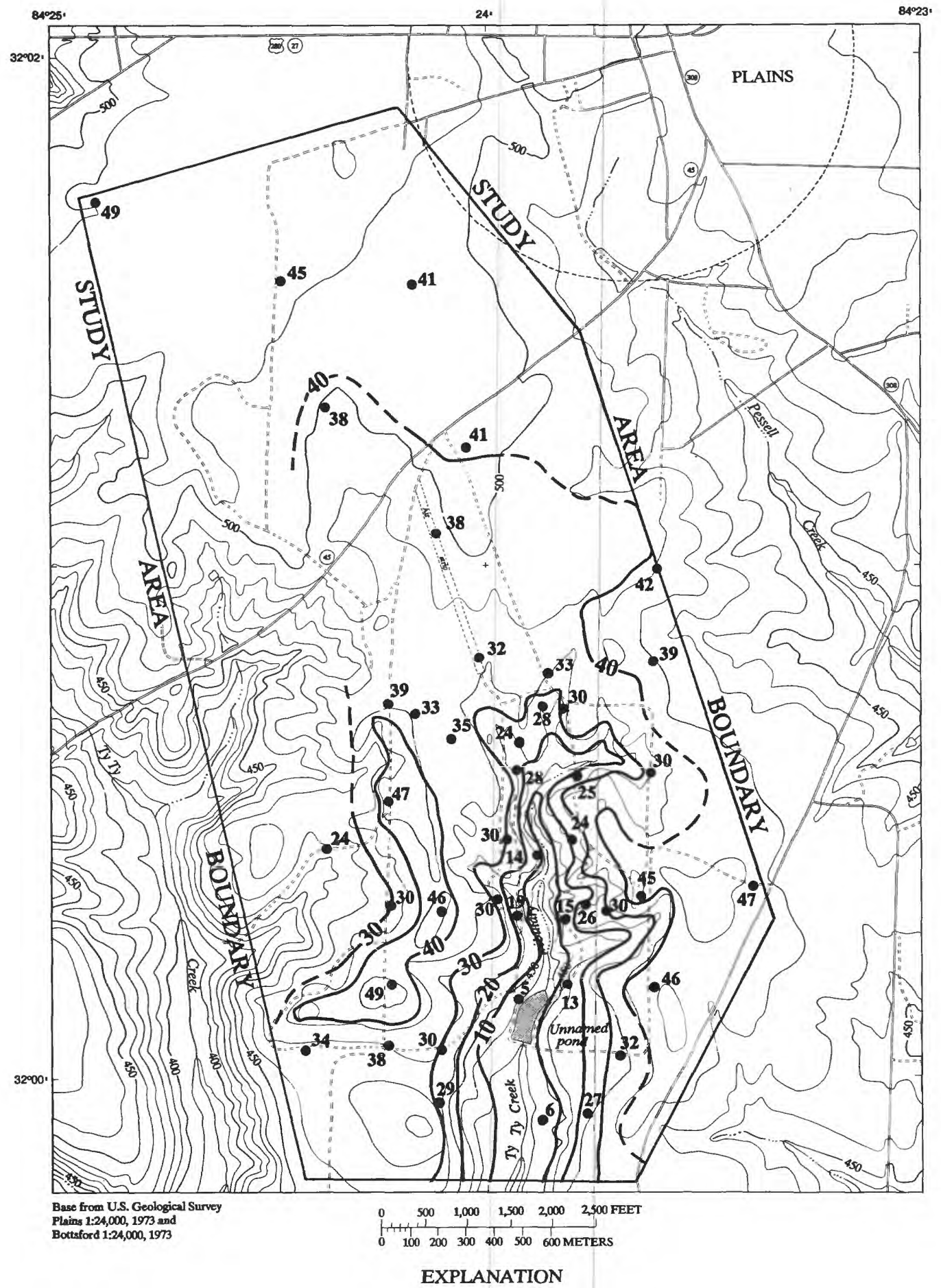

$\begin{gathered}\text { LINE OF EQUAL THICKNESS OF UNSATURATED ZONE- } \\ \text { Dashed where approximately located. Interval } 10 \text { feet }\end{gathered}-\bullet^{5} \quad \begin{gathered}\text { WELL LOCATION-Number is approximate } \\ \text { thickness of the unsaturated zone, in feet }\end{gathered}$

Figure 5.--Approximate thickness of the unsaturated zone, June 1986. 


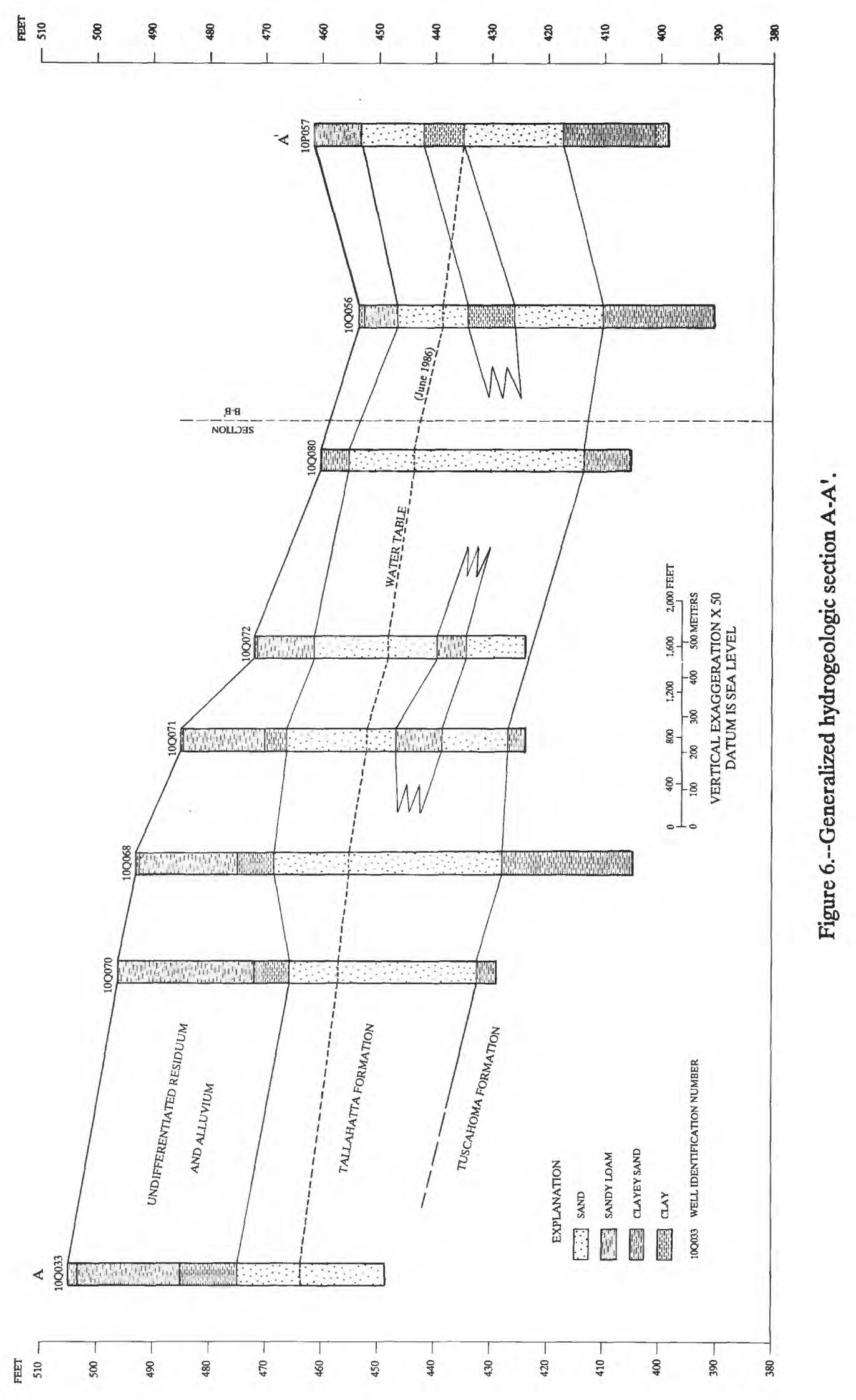




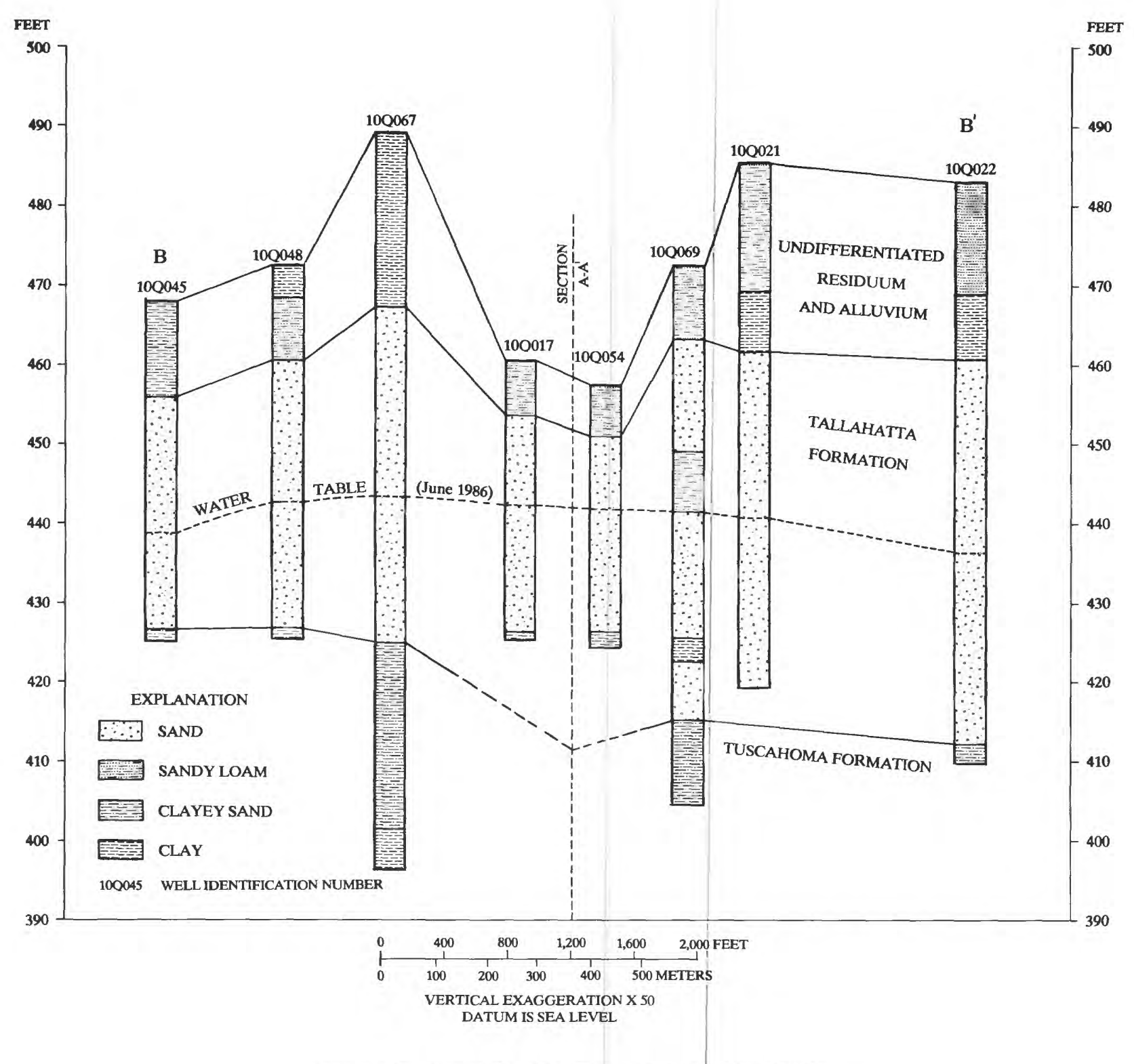

Figure 7.--Generalized hydrogeologic section B-B'.

\section{Undifferentiated Residuum and Alluvium}

In the interstream and the upper part of the midslope areas, the Tallahatta Formation is overlain by a 2- to 16-ft layer of dense, massive, red to white, commonly mottled clay residuum that probably was derived from sediments younger than the Tallahatta. In these areas, the clay is overlain by 22 to $26 \mathrm{ft}$ of interlayered sandy clay, quartz sand, and dark red clay. The clayey part of the residuum progressively thins through the midslope area and is absent in the lower part of the midslope area and toe-slope areas. In those areas having land-surface altitudes of less than about $470 \mathrm{ft}$, the clay residuum is absent and the overburden consists of permeable silty sand. The clayey residuum layer probably was removed by erosion in the low-lying areas. The streambed of the Ty Ty Creek tributary is filled by 7 to $11 \mathrm{ft}$ of red to brown clay, silt, and sand alluvium. The thickness of the undifferentiated residuum and alluvium ranges from about 40 $\mathrm{ft}$ at well 34 to less than $10 \mathrm{ft}$ at well 37. 


\title{
HYDROLOGY
}

\author{
Rainfall
}

Rainfall records at the University of Georgia Experiment Station at Plains indicate that since rainfallrecord keeping began in 1958, the annual rainfall totals have ranged from 38.7 to 70.6 in., and averaged 49.3 in. For the 12-month period of May 1985 through April 1986, rainfall in the study area totaled 47.9 in., or about $1.4 \mathrm{in}$. less than the 28-year average at Plains.

In southwestern Georgia, rainfall totals during the periods January through March and June through August normally are about equal, but the duration, intensity, and areal distribution of the rainfall differ greatly. However, this normal distribution of rainfall did not occur during 1986 . Figure 8 shows daily cumulative rainfall averaged from the four rain gages in the study area. Rainfall during January through March 1986 (9.5 in.) was 7.4 in. less than during June through August 1985 (16.9 in.). The monthly total of 0.4 in. for April 1986 observed in the study area was the lowest on record for the Plains area.

Rainfall data collected at four sites in the study area indicate that areal variability is most pronounced during the summer months as a result of intense thunderstorms. During July 1985, total rainfall ranged from $7.1 \mathrm{in}$. in the northern part of the study area to $9.9 \mathrm{in}$. in the southern area.

\section{Surface-Water Hydrology}

Runoff is monitored at three sites in the watershed. Runoff from the northern part of the watershed is gaged at a slope-area discharge station consisting of two recorder installations (SW-1 and SW-2) (fig. 2). Runoff from a 20-acre watershed that is tributary to the Ty Ty Creek tributary is gaged at site SW-3. The total runoff and baseflow discharge from the watershed are monitored at the unnamed pond by a stage recorder (SW-4) and an outflow recorder (SW-5).

Sites SW-1 and SW-2 are located near the headwater of Ty Ty Creek tributary, which drains a 294acre, mixed-cover watershed (fig. 2). Site SW-1 (upstream) and site SW-2 (downstream) are equipped with primary and backup recorders. Discharge measurements used to develop a stage-discharge relation were made at a channel section $20 \mathrm{ft}$ downstream from site SW-2.

On February 1, 1985, several months prior to instrumentation of stations SW-1 and SW-2, a 2-day storm produced more than $4 \mathrm{in}$. of rainfall, which resulted in a peak discharge of more than $300 \mathrm{ft}^{3} / \mathrm{s}$ at this site (computed by the indirect method). Peak-stage data from a nearby stream, Choctahatchee Creek tributary (1.2 mi northwest of the study area), indicated that this storm had a recurrence interval of about 5 years (T.W. Hale, USGS, written commun., 1985).

Between July 1985 (when monitoring equipment was installed at the station) and May 1986, four storms produced measurable flows. The volumes of runoff were estimated based on cross-sectional channel profiles, channel slope, assumed friction value (channel roughness), assumed storm hydrograph, and the recorded time-of-flow. Estimated total runoff for the four storms was $0.44 \mathrm{in}$. over the drainage area (Joseph Sheridan, ARS, Tifton, written commun., 1986). Accurate computation of storm runoff at the slope-area station will not be possible until measureable runoff occurs and a stage-discharge rating is developed.

Runoff from a 20-acre watershed on the west side of the study area is monitored at site SW-3 (fig. 2). Discharge from the watershed is metered through a calibrated, 25 -ft-wide, V-notch weir. A record of pool stage in the weir throat is obtained by recorders on primary and backup stilling wells installed at the weir. 


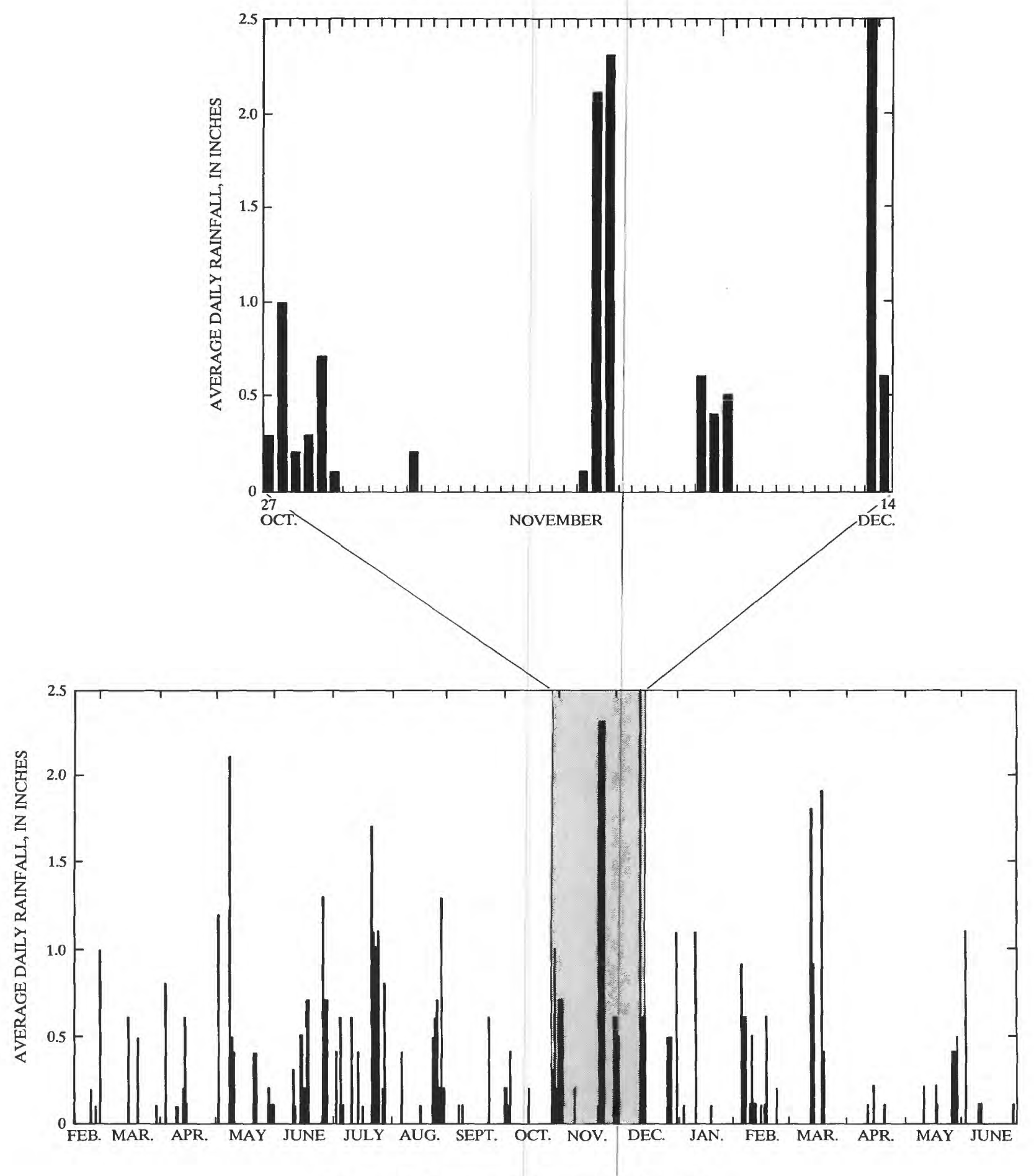

Figure 8.--Average daily rainfall, 1985-86.

Total surface runoff from the 20-acre watershed for the period June 1985 through April 1986 was $1.39 \mathrm{in.}$ over the drainage area (Joseph Sheridan, ARS, Tifton, written commun., 1986). This volume of runoff resulted from a total rainfall of $42.7 \mathrm{in.}$ Seventeen rainfall events during the period resulted in runoff amounts exceeding 0.01 in. over the drainage area, and nine rainfall events produced runoff in excess of $0.1 \mathrm{in}$. The maximum rainfall runoff was $0.44 \mathrm{in}$. over the drainage area, which resulted from rainfall of 4.4 in. that occurred November 21-22, 1985. Runoff from the 20-acre watershed accounted for as much as 31 percent of total rainfall that occurred during any one event. 
Downstream from the slope-area station (sites SW-1 and SW-2), Ty Ty Creek tributary receives ground-water discharge from seep springs in the streambed. Farther downstream, the streamflow is impounded in the unnamed pond, which has a total contributing drainage area of about 460 acres (fig. 2). The pond stage is monitored by a continuous recorder installed on a stilling well in the pond (SW-4) and the outflow is monitored at the drainpipe (SW-5).

Records from site SW-4 indicate that the pond stage fluctuated $0.89 \mathrm{ft}$ during the 14-month period, March 1985 through April 1986, in response to rainfall and to changes in the ground-water level and evapotranspiration losses (fig. 9). Although maximum pond stage is limited by the altitude of a vertical drainpipe and an emergency spillway, peaks of short duration slightly exceed the altitude of the pipe. However, during late summer and early fall when the ground-water level is approaching an annual low, evapotranspiration losses are at a maximum, and rainfall is at a minimum, the pond stage generally remains below the altitude of the pipe and outflow is limited to seepage through joints in the drainpipe. Maximum and minimum pond stages during the 14-month period were 439.16 (July 26, 1985) and $438.27 \mathrm{ft}$ (Oct. 27, 1985), respectively.

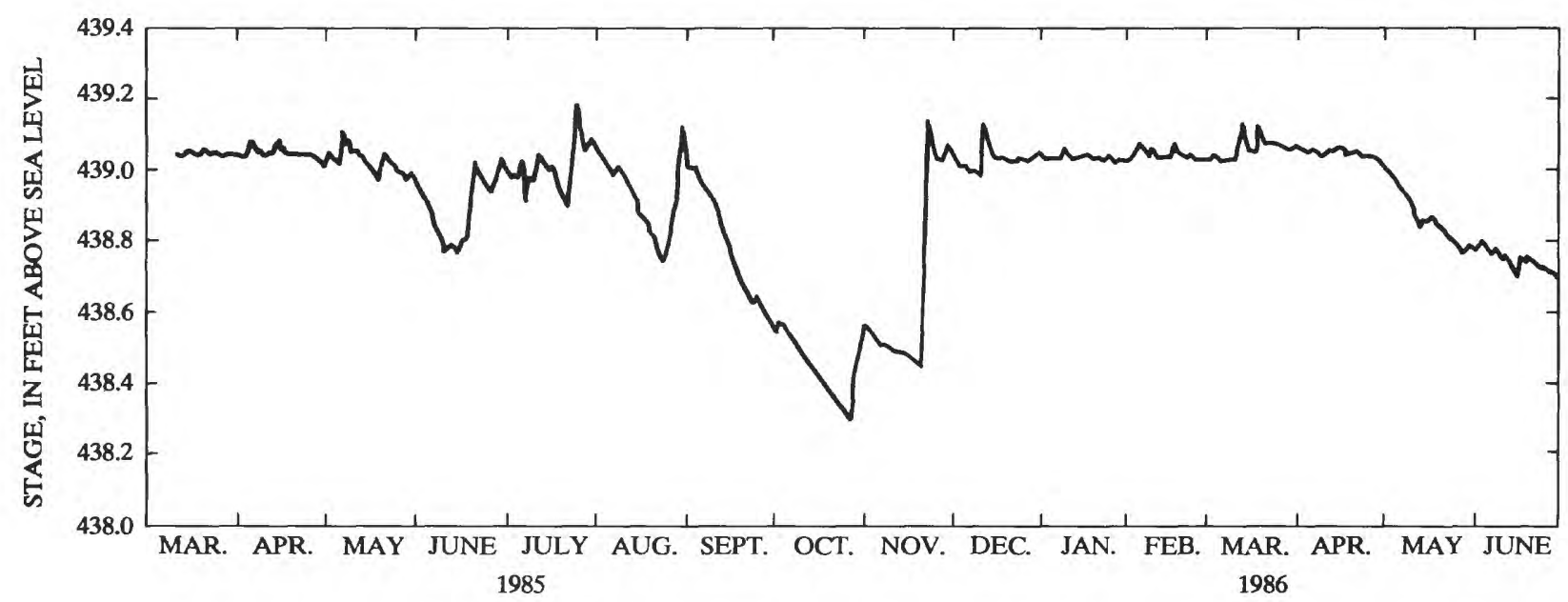

Figure 9.--Daily stage fluctuations in the unnamed pond, 1985-86.

Outflow from the unnamed pond passes through a calibrated $\mathrm{H}$-flume that is attached to the drainpipe and equipped with a continuous recorder at site SW-5. During the 12-month period, May 1985 through April 1986, the pond stage did not exceed the altitude of the emergency spillway and all pond outflow was measured by the $\mathrm{H}$-flume. Total pond outflow during the 12-month period, or total yield from the 460-acre contributing area, coupled with an undetermined volume of ground-water discharge, was 0.50 in. over the drainage area. A maxium monthly total outflow of 0.12 in. over the drainage area occurred during March 1986.

Evapotranspiration losses from the pond were not determined; and thus, were not included in the total calculations of outflow from the pond. Because evapotranspiration losses from the pond are quickly replaced by ground-water discharge, the loss during periods of minimal rainfall and runoff, particularly during April through November, could represent a large component of ground-water discharge, and ultimately, pond outflow that does not pass through the H-flume. 


\section{Ground-Water Hydrology}

The hydrogeologic units important to this study can be divided into two zones, the unsaturated zone and the saturated zone. The unsaturated zone includes the alluvium, the undifferentiated residuum, and the upper part of the Tallahatta Formation. The saturated zone is restricted to the lower part of the Tallahatta Formation, which forms the Claiborne aquifer in this area.

\section{Unsaturated zone}

The unsaturated zone contains water in the gas phase under atmospheric pressure, water temporarily or permanently under less-than-atmospheric pressure, and air or other gases (Lohman, 1972). Sand, sandy clay, and clay in the unsaturated zone in the study area also may be temporarily saturated with water under less-than-atmospheric pressure. The upper part of the unsaturated zone may be temporarily saturated during or after periods of rainfall. The thickness of the zone of temporary saturation and the rate of moisture propagation depends on several factors, including soil density and compaction, soil particle-size distribution, soil-moisture deficit, slope, and rainfall rate (Carson and Kirkby, 1972).

Because of the areal variability of the soils, the lithology of the undifferentiated overburden, the topographic relief, and the temporal variability of vegetative land cover and land use, it is assumed that rates of infiltration in the study area vary substantially. In the farmed interstream and upper part of the midslope areas, the sloping, clayey, surficial soils generally are characterized by high surface runoff and limited vertical infiltration. However, in the lower part of the midslope areas and in the toe-slope areas the slope of the land surface is more gentle and the surface soils generally are more sandy; thus, the areas are more favorable to infiltration. During pit excavation in the lower part of a midslope area, rainfall of $2.5 \mathrm{in}$. (occurring Oct. 27-31, 1985) infiltrated to a depth of 19.6 in. (measured Oct. 31) in a sandy soil (fig. 8). The same rainfall produced observable runoff and infiltration to a depth of only $3.2 \mathrm{in.}$ (also measured Oct. 31) in a clayey soil in an interstream area.

The thickness of the unsaturated zone varies areally and temporally, and ranges from less than 10 $\mathrm{ft}$ in the downslope areas near the streambed of Ty Ty Creek tributary, to more than $50 \mathrm{ft}$ in the interstream areas (fig. 5). Seasonal fluctuations in the altitude of the water table result in changes in the thickness of the unsaturated zone. The maximum thickness of the unsaturated zone occurs during late fall when the altitude of the water table is at its seasonal low. Correspondingly, the thickness of the unsaturated zone is at its minimum in late spring following the ground-water-recharge season.

At the base of the unsaturated zone is the capillary fringe, which is the transition zone between the unsaturated and saturated zones, where water occurs under less-than-atmospheric pressure. The capillary fringe can range in thickness from less than one inch in coarse gravel to more than $5 \mathrm{ft}$ in clayey material (Lohman, 1972, p. 2). In the study area, the capillary fringe occurs in the relatively clean sand of the upper part of the Tallahatta Formation, and probably is only a few inches thick.

\section{Saturated zone}

The saturated zone in the Tallahatta Formation (Claiborne aquifer) is the primary source of water for domestic, rural, and municipal wells in the Plains area. Downdip to the south and southeast of the study area, the Claiborne aquifer is a major source of water for industrial, agricultural, and municipal use.

The top of the saturated zone is referred to as the water table, and is the level at which water stands in a well that taps this zone. The thickness of the saturated zone is dependent on the thickness of the Tallahatta Formation and the altitude of the water table. Structural alteration and erosion have resulted in irregularities in the upper surface and thickness of the the Tallahatta (T.G. Gibson, USGS, oral commun., 1986). Moreover, variations in ground-water recharge and discharge result in water-table fluctuations. Thus, the thickness of the saturated zone varies areally and temporally (figs. 6 and 7), and generally increases to the southeast, and ranges from about 11 to $49 \mathrm{ft}$ in the study area. 


\section{Water-table fluctuation}

The altitude of the water table is controlled primarily by the rate of recharge, the rate of discharge (both natural and induced), the topography, and atmospheric pressure. During June 1986, the water table in the Claiborne aquifer ranged from $466 \mathrm{ft}$ in the northern part of the area to $434 \mathrm{ft}$ at the southern boundary, and had a nearly uniform slope to the south of about $16.5 \mathrm{ft} / \mathrm{mi}$ (fig. 10).

The flow lines shown on figure 10 indicate that the lateral component of ground-water flow generally is from north to south throughout the study area. However, the configuration of the water table may change slightly during years of above-normal rainfall.

The correlation among average daily rainfall; pond stage; and the water levels in wells $38,70,71$, and 72 illustrates the effect of recharge and discharge on the ground-water level (figs. 8, 9, 11, and 12). During the winter months (December through March), when vegetation growth and solar radiation are at a minimum and evapotranspiration losses are low, the Claiborne aquifer receives the maximum recharge. As a result, the ground-water level recovers from the low of the previous year and normally reaches an annual high by April or May. Although rainfall can be intense from June through early August, water lost to evapotranspiration and surface runoff is high, and the amount of water available for recharge is reduced. Thus, reduced recharge and increased discharge causes the ground-water level to decline to a minimum by late fall. The annual water-level fluctuation in well 70 from July 1985 through May 1986 was $0.8 \mathrm{ft}$. Downslope, where the unsaturated zone is thinner and more permeable, the water level in wells 38,71 , and 72 fluctuated about $1.3 \mathrm{ft}$ during the same period.

\section{Rainfall and recharge relation}

That part of the rainfall that does not run off, or is not lost to evapotranspiration, infiltrates into the ground. Part of the infiltrating water replenishes the soil-moisture and the remainder percolates through the unsaturated zone and recharges the saturated zone. The saturated zone provides baseflow to the Ty Ty Creek tributary, as well as other area streams.

Several factors control the distribution of rainfall in the watershed. Thus, the amount of recharge available to the saturated zone, and the rate and volume of discharge to Ty Ty Creek tributary, vary areally and temporally.

Recharge to the Claiborne aquifer consists of a regional and a local component, and for comparative purposes, is assumed to be represented by the seasonal ground-water-level fluctuation (seasonal low to seasonal high). Regional recharge, as referred to in this report, is recharge that enters the ground-water system upgradient, outside the confines of the study area, and is dependent on regional hydrologic controls (pumpage, stream discharge, and rainfall). The rate of lateral movement of regional recharge into the area is dependent on the hydraulic conductivity of the saturated zone, the hydraulic gradient, and other hydraulic factors, and is considered to be relatively constant.

Ground-water-level changes from July 1985 to May 1986 ranged from 6.4 in. at well 34, in the northwestern part of the study area, to 22.3 in. downgradient at well 39 (fig. 12), in response to a total rainfall of 37.6 in. Although the regional and local recharge components cannot be accurately separated, because well 34 is near the updip boundary of the study area where the unsaturated zone is relatively thick and semipermeable, the seasonal water-level fluctuation of 6.4 in. is assumed to result primarily from regional recharge. Thus, if the seasonal water-level fluctuation of $22.3 \mathrm{in}$. at well 39 was reduced by the assumed regional recharge component that results in the water-table rise of 6.4 in. observed at well 34 , the resultant 15.9 in. suggests that the Claiborne aquifer receives recharge in the study area (fig. 12). 


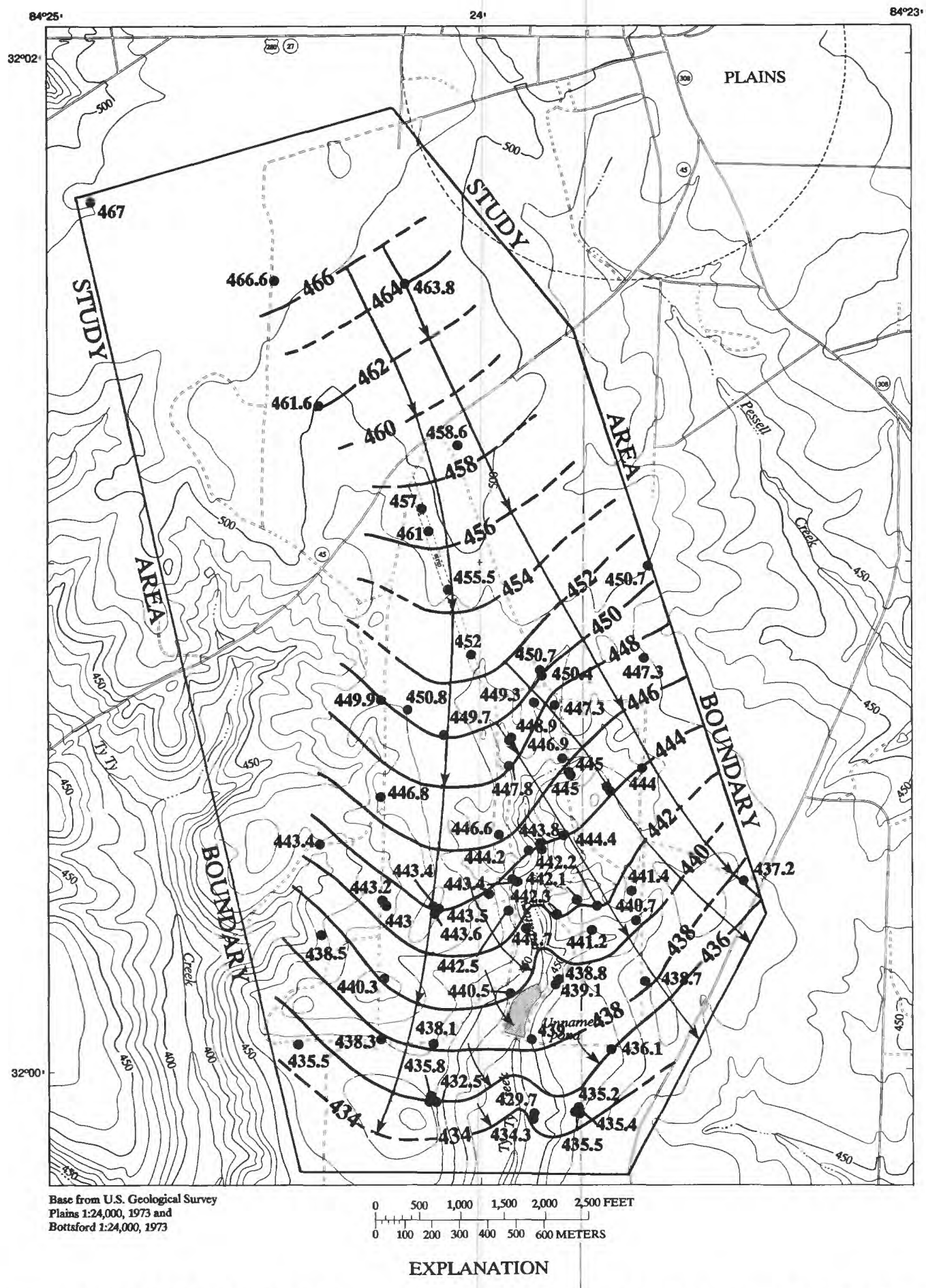

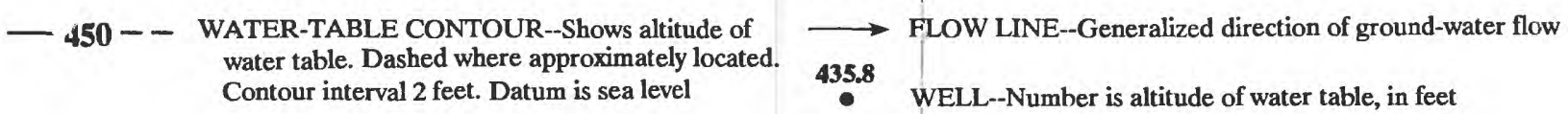

Figure 10.--Water-table altitude and generalized direction of ground-water flow in the Claiborne aquifer, June 1986. 

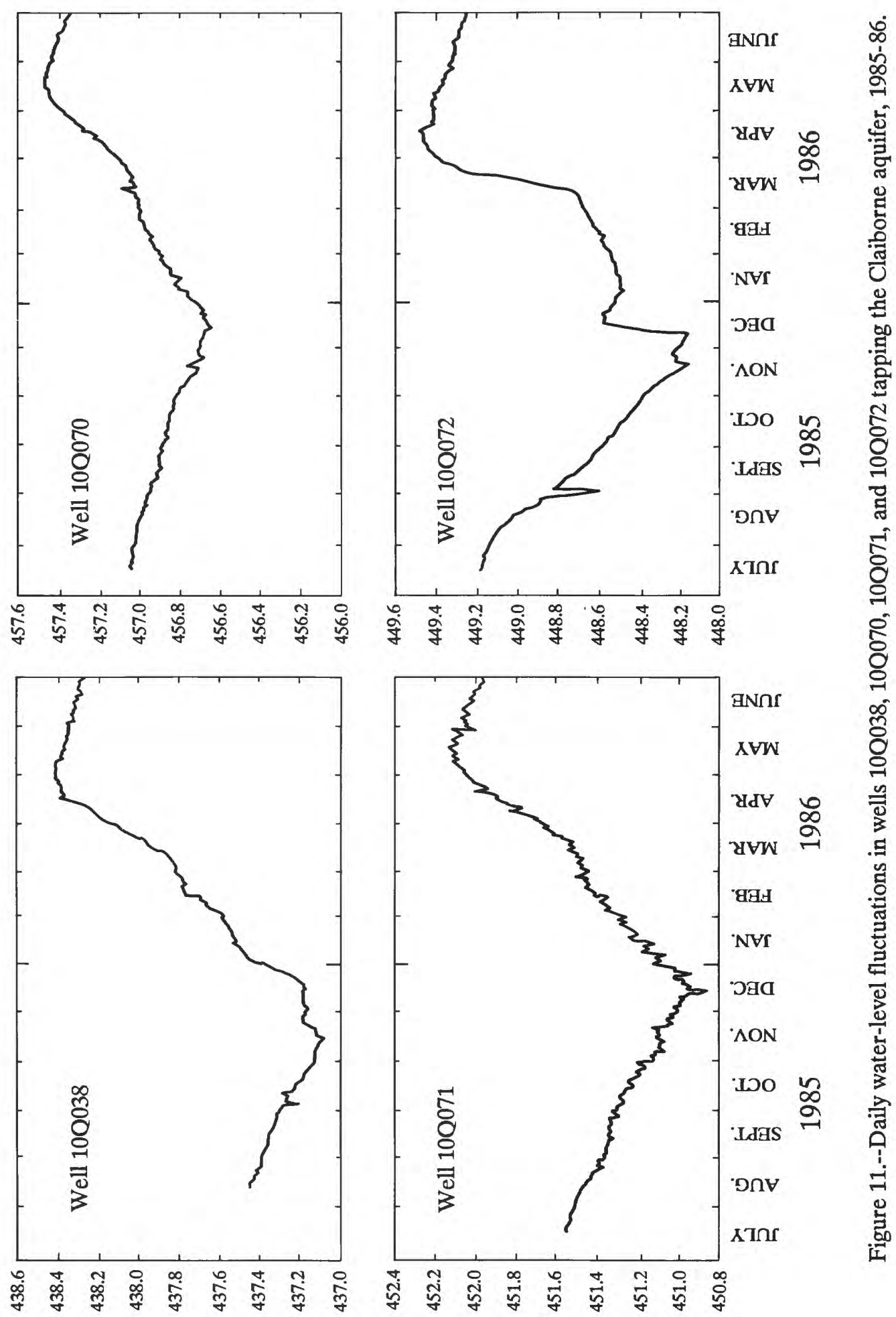

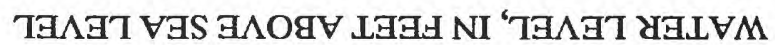




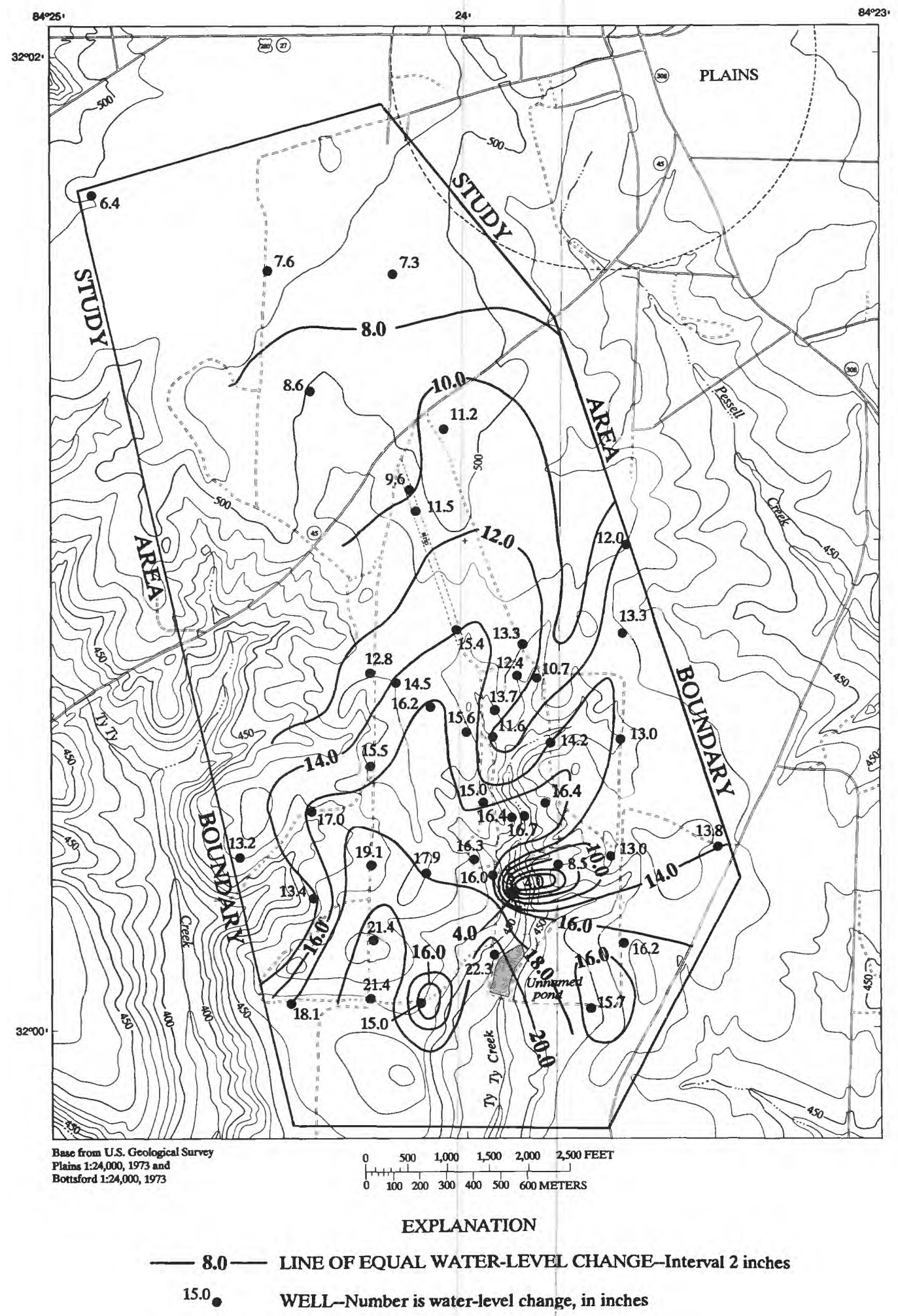

Figure 12.--Water-level change in the Claiborne aquifer, July 1985 to June 1986. 
The quantity of ground-water recharge, as indicated by change in ground-water level (fig. 12), increases downgradient through the watershed. Other hydraulic factors, such as the geometry of the saturated zone and stream boundary conditons, may affect the net water-table fluctuation. Thus, the water-level fluctuation observed in the study area cannot be attributed entirely to local recharge. However, it is likely that relatively rapid recharge probably occurs in parts of the midslope and toe-slope areas where the land surface is nearly flat, the overland runoff velocity is low, and the undifferentiated residuum and alluvium is more permeable.

Maximum ground-water recharge occurs during the winter months when storms produce heavy rainfall over several days and evapotranspiration losses are at a minimum. Recharge of the saturated zone does not begin, however, until the soil-moisture deficit in the unsaturated zone has been overcome. For example, cummulative rainfall of more than 7 in. during the periods October 27-31 (2.50 in.) and November 21-22 (4.52 in.) in 1985, resulted in a water-level rise of only 0.6 in. at well 72 (figs. 8 and 11). This well is in the part of the midslope area where rapid recharge would be anticipated. Because of the moisture deficit in the unsaturated zone, a large part of the water infiltrating into the ground was retained in the unsaturated zone. Rainfall during this period apparently overcame the moisture deficit in the unsaturated zone at well 72 , because subsequent rainfall resulted in a more direct response in the water level in the saturated zone. Rainfall on December 12-13, 1985, totaled only 3.10 in., but resulted in a water-level rise of 5.04 in. at well 72.

Moisture conditions in the unsaturated zone control not only the quantity of recharge water that passes through it and into the saturated zone, but the rate of response. After the moisture deficit in the unsaturated zone is overcomed, the time lag between rainfall and the water-level response in the saturated zone appears to be reduced. To evaluate the relation between moisture condition in the unsaturated zone and the water-level response in the saturated zone, detailed moisture, rainfall, and ground-water-level data are needed.

\section{Water Quality}

\section{Surface-water quality}

Water-quality data from sites AS-1, AS-2, and AS-3 upstream of the unnamed pond are limited. Since the fall of 1985 when the sites were instrumented, rainfall runoff has been insufficient to permit sample collection at sites AS-1 and AS-2, and only two samples were collected at site AS-3. Data for the pond-outflow site (AS-4) are more abundant.

Runoff samples collected at site AS-3 during two rainfall events were analyzed for concentrations of suspended sediment and selected inorganic constituents. Samples collected at site AS-4 were analyzed for selected concentrations of inorganic constituents (table 3). Runoff from the watershed was low in dissolved constituents. Specific conductance generally was less than $50 \mu \mathrm{S} / \mathrm{cm}$. At site AS-3 specific conductance and chloride concentration of runoff samples ranged from 22 to $46 \mu \mathrm{S} / \mathrm{cm}$ and 1.5 to 7.4 $\mathrm{mg} / \mathrm{L}$, respectively. At the pond-outflow site (AS-4), specific conductance and chloride concentration of composite samples ranged from 18 to $57 \mu \mathrm{S} / \mathrm{cm}$ and 2.1 to $5.0 \mathrm{mg} / \mathrm{L}$, respectively. The concentration of inorganic nitrogen, which is the sum of the ammonia, nitrite, and nitrate-nitrogen concentrations, ranged from 0.19 to $1.50 \mathrm{mg} / \mathrm{L}$ at site AS-3 and from 0.11 to $2.02 \mathrm{mg} / \mathrm{L}$ at site AS-4.

Currently, data are too sparse to assess the water-quality characteristics of runoff directly from the farmed part of the study area, or to assess the impact of the pond on water quality at the pond-outflow site (AS-4). 
Table 3.--Results of chemical and suspended sediment analyses of rainfall runoff and surface water from the Ty Ty Creek tributary watershed, 1985-86

[mg/L, milligrams per liter; ppm, parts per million; $\mu \mathrm{S} / \mathrm{cm}$, microsiemens per centimeter at 25 degrees Celcius; <, less than detection level; --, no data]

\begin{tabular}{|c|c|c|c|c|c|c|c|c|c|c|}
\hline \multirow[b]{2}{*}{ Site } & \multirow{2}{*}{$\begin{array}{c}\text { Sample } \\
\text { date }\end{array}$} & \multirow{2}{*}{$\begin{array}{c}\text { Number } \\
\text { of } \\
\text { analyses }\end{array}$} & \multicolumn{2}{|c|}{$\begin{array}{c}\text { Specific } \\
\text { conductance } \\
(\mu \mathrm{S} / \mathrm{cm})\end{array}$} & \multirow{2}{*}{$\begin{array}{l}\text { Number } \\
\text { of } \\
\text { analyses }\end{array}$} & \multicolumn{2}{|c|}{$\begin{array}{l}\text { Chloride } \\
\text { (mg/L) }\end{array}$} & \multirow{2}{*}{$\begin{array}{c}\text { Number } \\
\text { of } \\
\text { analyses }\end{array}$} & \multicolumn{2}{|c|}{$\begin{array}{l}\text { Ammonia- } \\
\text { nitrogen } \\
(\mathrm{mg} / \mathrm{L}\end{array}$} \\
\hline & & & mean & range & & mean & range & & mean & range \\
\hline \multirow[t]{2}{*}{ AS 3} & $03-13-86$ & 23 & 32 & $\begin{array}{l}22 \\
\text { to } \\
46\end{array}$ & 23 & 3.6 & $\begin{array}{l}2.3 \\
\text { to } \\
5.5\end{array}$ & 23 & 0.18 & $\begin{array}{r}0.04 \\
\text { to } \\
0.30\end{array}$ \\
\hline & $03-19-86$ & 24 & 20 & $\begin{array}{l}20 \\
\text { to }\end{array}$ & 24 & 3.3 & $\begin{array}{l}1.5 \\
\text { to }\end{array}$ & 24 & .18 & $\begin{array}{r}.03 \\
\text { to }\end{array}$ \\
\hline \multirow[t]{3}{*}{ AS 4} & $\begin{array}{c}03-13-86 \\
\text { to } \\
03-25-86\end{array}$ & 21 & 25 & $\begin{array}{l}22 \\
18 \\
\text { to } \\
31\end{array}$ & 21 & 3.0 & $\begin{array}{l}7.4 \\
2.1 \\
\text { to } \\
5.0\end{array}$ & 27 & .04 & $\begin{array}{r}.23 \\
<.01 \\
\text { to } \\
.08\end{array}$ \\
\hline & $\begin{array}{c}04-03-86 \\
\text { to } \\
04-30-86\end{array}$ & 57 & 27 & $\begin{array}{l}20 \\
\text { to } \\
57\end{array}$ & 50 & 3.1 & $\begin{array}{l}2.5 \\
\text { to } \\
4.0\end{array}$ & 52 & .06 & $\begin{array}{r}.01 \\
\text { to } \\
.40\end{array}$ \\
\hline & $\begin{array}{c}05-07-86 \\
\text { to } \\
05-11-86\end{array}$ & 9 & 52 & $\begin{array}{l}51 \\
\text { to } \\
55\end{array}$ & 10 & 4.0 & $\begin{array}{l}3.5 \\
\text { to } \\
4.4\end{array}$ & 10 & 1.72 & $\begin{array}{r}1.41 \\
\text { to } \\
2.02\end{array}$ \\
\hline \multirow[b]{2}{*}{ Site } & \multirow{2}{*}{$\begin{array}{c}\text { Sample } \\
\text { date }\end{array}$} & \multirow{2}{*}{$\begin{array}{c}\text { Number } \\
\text { of } \\
\text { analyses }\end{array}$} & \multicolumn{2}{|c|}{$\begin{array}{l}\text { Nitrate- } \\
\text { nitrogen } \\
(\mathrm{mg} / \mathrm{L})\end{array}$} & \multirow{2}{*}{$\begin{array}{l}\text { Number } \\
\text { of } \\
\text { analyses }\end{array}$} & \multicolumn{2}{|c|}{$\begin{array}{l}\text { Nitrite- } \\
\text { nitrogen } \\
(\mathrm{mg} / \mathrm{L})\end{array}$} & \multirow{2}{*}{$\begin{array}{c}\text { Number } \\
\text { of } \\
\text { analyses }\end{array}$} & \multicolumn{2}{|c|}{$\begin{array}{l}\text { Suspended } \\
\text { sediment } \\
(\mathrm{mg} / \mathrm{L})\end{array}$} \\
\hline & & & mean & range & & mean & range & & mean & range \\
\hline \multirow[t]{2}{*}{ AS 3} & $03-13-86$ & 23 & 0.42 & $\begin{array}{c}0.14 \\
\text { to } \\
1.20\end{array}$ & 24 & $<0.01$ & -- & 24 & 1,670 & $\begin{array}{r}120 \\
\text { to } \\
4,000\end{array}$ \\
\hline & $03-19-86$ & 24 & .30 & $\begin{array}{l}.19 \\
\text { to } \\
.63\end{array}$ & 24 & $<.01$ & -- & -- & -- & -- \\
\hline AS 4 & $\begin{array}{c}03-13-86 \\
\text { to } \\
03-25-86\end{array}$ & 23 & .06 & $\begin{array}{c}<.01 \\
\text { to } \\
.18\end{array}$ & 19 & $<.01$ & -- & -- & -- & -- \\
\hline & $\begin{array}{c}04-03-86 \\
\text { to } \\
04-30-86\end{array}$ & 52 & .02 & $\begin{array}{r}.01 \\
\text { to } \\
.14\end{array}$ & 52 & $<.01$ & -- & -- & -- & -- \\
\hline & $\begin{array}{c}05-07-86 \\
\text { to } \\
05-11-86\end{array}$ & 10 & $<.01$ & -- & 9 & $<.01$ & -- & -- & -- & -- \\
\hline
\end{tabular}




\section{Ground-water quality}

Ground-water samples were analyzed for seven herbicides, three nematicides, and one fungicide (tables 2 and 4) (table 4 is in the back of this report). Pesticides were not detected at the microgram per liter concentration. The water is not highly mineralized. Specific conductance generally was less than 60 $\mu \mathrm{S} / \mathrm{cm}$ and ranged from 16 to $70 \mu \mathrm{S} / \mathrm{cm}$ for ground-water samples collected during 1985-86. The nitratenitrogen concentrations ( $<0.01$ to $5.11 \mathrm{mg} / \mathrm{L}$ ) also were low. Ground-water samples having the highest specific conductance and nitrate concentration were from wells in the cultivated part of the midslope and toe-slope areas where geologic and hydrologic data indicate that rapid recharge occurs. Ground water in the watershed is acidic as indicated by the pH range of 4.5 to 5.6. The acidic water may have important implications to the mobility and fate of pesticides because of its affect on the solubility of some pesticides.

\section{SUMMARY}

(1) Geologic units of importance to the shallow ground-water system in the study area are, in ascending order, the Tuscahoma Formation, a homogeneous, well sorted, glauconitic, very fine to fine, clayey sand; the Tallahatta Formation, a fine to coarse, quartz sand; and the undifferentiated residuum and alluvium, alternating and intermittent layers of sand, clayey sand, and clay.

(2) The unsaturated zone includes the undifferentiated residuum and alluvium and the upper part of the Tallahatta Formation, and ranges in thickness from less than $10 \mathrm{ft}$ in the bed of Ty Ty Creek tributary, to more than $50 \mathrm{ft}$ in interstream (interfluve) areas. Preliminary data indicate that the vertical hydraulic conductivity of the unsaturated zone, as indicated by recharge rates, is greatest in the lower part of the midslope areas, and in the toe-slope areas where the unsaturated zone is relatively thin and permeable. In the interstream areas, the clayey part of the unsaturated zone causes the vertical hydraulic conductivity to be low.

(3) The saturated zone is restricted to the lower part of the Tallahatta Formation, and ranges in thickness from about 11 to $49 \mathrm{ft}$. It is underlain by the Tuscahoma Formation, and generally, is unconfined.

(4) During June 1986, the altitude of the water table ranged from $466 \mathrm{ft}$ in the northern part of the area to $434 \mathrm{ft}$ at the southern boundary, and had a nearly uniform slope of about $16.5 \mathrm{ft} / \mathrm{mi}$. The lateral component of ground-water flow in the watershed generally is from north to south. The water-level fluctuation during the period July 1985 to May 1986, ranged from $6.4 \mathrm{in}$. in the northern part of the area to $22.3 \mathrm{in}$. in the southern part, in response to rainfall totalling 37.6 in.

(5) Ground-water recharge seems to increase downgradient through the watershed. Relatively rapid recharge probably occurs in parts of the midslope and toe-slope areas where the land surface is nearly flat, and where the undifferentiated residuum is less than 12-ft thick and more permeable than in the upper part of the midslope and interstream areas.

(6) Moisture conditions in the unsaturated zone controls the quantity of recharge passed to the saturated zone and the time lag between rainfall and water-level response in the saturated zone.

(7) Analyses of surface-water samples indicate that in 1986 runoff from the watershed was low in dissolved constituents; specific-conductance values and chloride concentrations ranged from 22 to 46 $\mu \mathrm{S} / \mathrm{cm}$ and 1.5 to $7.4 \mathrm{mg} / \mathrm{L}$, respectively, in runoff from a cultivated area. At the outflow of the unnamed pond, specific conductance and chloride concentrations of composite samples ranged from 18 to 57 $\mu \mathrm{S} / \mathrm{cm}$ and 2.1 to $5.0 \mathrm{mg} / \mathrm{L}$, respectively. Nitrate-nitrogen concentrations ranged from 0.19 to $1.50 \mathrm{mg} / \mathrm{L}$ in runoff samples from the field, and from 0.11 to $2.02 \mathrm{mg} / \mathrm{L}$ at the pond outflow. 
(8) Pesticides (at the microgram per liter concentration) were not detected in ground-water samples from the watershed. The mineral content of the ground water was low. Specific conductance ranged from 16 to $70 \mu \mathrm{S} / \mathrm{cm}$, and nitrate-nitrogen concentrations ranged from less than <0.01 to 5.11 $\mathrm{mg} / \mathrm{L}$. Samples that had the highest specific conductance and nitrate concentration were from wells located in the cultivated, lower part of the midslope and toe-slope areas. Ground water in the watershed had a pH that ranged from 4.5 to 5.6. The acidic ground water may have important implications to the mobility and fate of pesticides because of its affect on the solubility of some pesticides.

\section{SELECTED REFERENCES}

Carson, M.A., and Kirkby, M.J., 1972, Hillslope form and process, Cambridge University Press, 475 p.

Clark, W.Z., Jr., and Zisa, A.C., 1976, Physiographic map of Georgia: Georgia Department of Natural Resources, Geologic and Water Resources Division; 1:2,000,000.

Cooke, C.W., 1943, Geology of the Coastal Plain of Georgia: U.S. Geological Survey Bulletin 941, p. 121, pl.1.

Farm Chemicals Handbook, 1989, Dictionary of pesticides and pesticide related products: Willoughby, Ohio, Meister Publishing Co., 666 p.

Georgia Geological Survey, 1976, Geologic map of Georgia, 1:500,000.

Herrick, S.M., 1961, Well logs of the Coastal Plain of Georgia: Georgia Geological Survey Bulletin 70, p. 358-373.

Hicks, D.W., Krause, R.E., and Clarke, J.S., 1981, Geohydrology of the Albany area, Georgia: Georgia Geologic Survey Information Circular 57, $31 \mathrm{p}$.

Horton, R.E., 1945, Erosional development of streams and their drainage basins: hydrophysical approach to quantitative morphology: Geological Society of America, Bulletin 56, p. 275-370.

LaForge, Laurence, Cook, Wythe, Keith, Arthur, and Campbell, M.R., 1925, Physical geography of Georgia: Georgia Geological Survey Bulletin 42, 189 p.

Lappenbusch, W.L., 1984, Health effects of drinking water contaminants: Ontario, Canada, in Proceedings of the 31st Ontario Industrial Waste Conference, Ontario Ministry of the Environment, p. 271-291.

Lohman, S.W., 1972, Ground-water hydraulics: U.S. Geological Survey Professional Paper 708, 70 p.

Owen, Vaux, Jr., 1963, Geology and ground-water resources of Lee and Sumter Counties, southwest Georgia: U.S. Geological Survey Water-Supply Paper 1666, 70 p.

Solley, W.B., Chase, E.B., and Mann, W.B., 1983, Estimated use of water in the United States in 1980: U.S. Geological Survey Circular 1001, $56 \mathrm{p}$.

The Merck Index, 1983, Chemicals, drugs, and biologicals: Rahway, NJ, Merck and Company, Inc., 10th ed, p. 1-1403.

Vorhis, R.C., 1972, Geohydrology of Sumter, Dooly, Pulaski, Lee, Crisp, and Wilcox Counties, Georgia: U.S. Geological Survey Hydrologic Atlas, HA-435, 2 pl. 
Table 4.--Results of analyses of chemical inorganic constitutents in ground water, 1985-86

$\left[{ }^{\circ} \mathrm{C}\right.$, degrees Celcius; $1 \mathrm{~S} / \mathrm{cm}$, microsiemens per centimeter; $\mathrm{mg} / \mathrm{L}$ as $\mathrm{CaCO}_{3}$, milligrams per liter as calcium carbonate; mg/L, milligrams per liter; <, less than detection level; --, not analyzed for]

\begin{tabular}{|c|c|c|c|c|c|c|c|c|c|c|}
\hline $\begin{array}{c}\text { Well } \\
\text { number }\end{array}$ & $\begin{array}{c}\text { Sample } \\
\text { date }\end{array}$ & $\begin{array}{c}\text { Water } \\
\text { tempera- } \\
\text { ture } \\
\left({ }^{\circ} \mathrm{C}\right)\end{array}$ & $\begin{array}{l}\text { Specific } \\
\text { conduct- } \\
\text { ance } \\
(\mu S / \mathrm{cm})\end{array}$ & $\mathrm{pH}$ & $\begin{array}{l}\text { Alkalinity } \\
\text { as } \mathrm{CaCO} \\
\text { (mg/L) }\end{array}$ & $\begin{array}{l}\text { Chloride } \\
\text { (mg/L) }\end{array}$ & $\begin{array}{l}\text { Ammonia- } \\
\text { nitrogen } \\
\text { as N } \\
(\mathrm{mg} / \mathrm{L})\end{array}$ & $\begin{array}{l}\text { Nitrate- } \\
\text { nitrogen } \\
\text { as } N \\
(\mathrm{mg} / \mathrm{L})\end{array}$ & $\begin{array}{l}\text { Nitrite- } \\
\text { nitrogen } \\
\text { as N } \\
(\mathrm{mg} / \mathrm{L})\end{array}$ & $\begin{array}{l}\text { O-phos- } \\
\text { phate } \\
\text { as P } \\
\text { (mg/L) }\end{array}$ \\
\hline \multirow{3}{*}{$10 Q 013$} & $03-26-86$ & 20.0 & 44 & 4.8 & 1 & 2.8 & 0.02 & 2.63 & $<0.01$ & -- \\
\hline & $04-22-86$ & 18.5 & 45 & 4.7 & 2 & 3.3 & $<.01$ & 2.43 & $<.01$ & -- \\
\hline & $05-22-86$ & 18.0 & 44 & 4.7 & -- & 3.2 & $<.01$ & 1.85 & $<.01$ & - \\
\hline \multirow[t]{2}{*}{ 10Q014 } & $10-03-85$ & -- & 20 & -- & -- & - & .04 & 1.71 & -- & - \\
\hline & $06-24-86$ & 19.5 & 35 & 5.0 & -- & 1.9 & $<.01$ & 1.40 & $<.01$ & - \\
\hline \multirow[t]{6}{*}{$10 Q 015$} & $08-27-85$ & -- & 37 & -- & -- & 4.6 & .02 & 2.68 & - & $<0.01$ \\
\hline & $09-19-85$ & -- & 40 & - & - & 4.4 & .01 & 3.01 & -- & $<.01$ \\
\hline & $10-03-85$ & -- & 25 & -- & -- & -- & .01 & 2.87 & -- & -- \\
\hline & $03-21-86$ & 17.5 & 44 & 4.6 & -- & 4.1 & $<.01$ & 2.01 & $<.01$ & -- \\
\hline & $04-22-86$ & 19.0 & 45 & 4.6 & 1 & 4.4 & $<.01$ & 2.43 & $<.01$ & -- \\
\hline & $05-21-86$ & 19.0 & 45 & 4.7 & - & 4.1 & $<.01$ & 1.87 & $<.01$ & - \\
\hline \multirow[t]{4}{*}{$10 Q 016$} & $10-03-85$ & - & 22 & -- & .- & -- & .02 & 1.60 & -- & -- \\
\hline & $03-27-86$ & 17.5 & 28 & 5.0 & 1 & 2.0 & .02 & 0.84 & $<.01$ & -- \\
\hline & $04-22-86$ & 17.0 & 28 & 5.0 & 4 & 2.8 & $<.01$ & .49 & $<.01$ & -- \\
\hline & $06-27-86$ & 18.0 & 28 & 5.0 & -- & 2.8 & $<.01$ & .89 & $<.01$ & - \\
\hline \multirow{6}{*}{$10 Q 017$} & $08-27-85$ & - & 32 & -- & -- & 3.3 & .03 & 2.40 & -- & $<.01$ \\
\hline & $09-19-85$ & -- & 37 & -- & -- & 3.4 & .02 & 2.88 & - & $<.01$ \\
\hline & $10-03-85$ & -- & 29 & - & -- & - & .04 & 2.60 & -- & - \\
\hline & $03-27-86$ & 18.5 & 39 & 4.7 & 1 & 3.0 & .04 & 2.27 & $<.01$ & -- \\
\hline & $04-22-86$ & 18.0 & 39 & 4.8 & 1 & 2.5 & $<.01$ & 2.28 & $<.01$ & -- \\
\hline & $05-21-86$ & 18.5 & 40 & 4.8 & -- & 2.8 & $<.01$ & 1.61 & $<.01$ & - \\
\hline $10 Q 018$ & $10-03-85$ & - & 32 & - & - & -- & $<.01$ & 3.20 & -- & -- \\
\hline \multirow[t]{6}{*}{$10 Q 019$} & $08-27-85$ & -- & 47 & -- & -- & 3.1 & .02 & 5.02 & -- & $<.01$ \\
\hline & $09-19-85$ & -- & 49 & - & -- & 3.3 & .05 & 4.96 & -- & $<.01$ \\
\hline & $10-03-85$ & -- & 42 & - & -- & -- & .04 & 4.76 & - & -- \\
\hline & $04-23-86$ & 17.5 & 57 & 4.6 & 1 & 2.9 & $<.01$ & 4.33 & $<.01$ & -- \\
\hline & $05-22-86$ & 17.0 & 55 & 4.6 & -- & 2.6 & $<.01$ & 3.56 & $<.01$ & -- \\
\hline & $06-26-86$ & 17.0 & 58 & 4.6 & - & 2.6 & $<.01$ & 4.07 & $<.01$ & - \\
\hline \multirow[t]{4}{*}{$10 Q 020$} & $08-27-85$ & - & 32 & -- & - & 2.7 & .03 & 2.80 & -- & $<.01$ \\
\hline & $09-19-85$ & -- & 39 & -- & -- & 3.4 & .03 & 3.38 & -- & $<.01$ \\
\hline & $10-03-85$ & -- & 32 & -- & - & -- & $<.01$ & 3.00 & - & -- \\
\hline & $06-26-86$ & 17.5 & 38 & 4.8 & - & 2.0 & $<.01$ & 2.34 & $<.01$ & - \\
\hline \multirow[t]{3}{*}{100021} & 10-03-85 & -- & 27 & -- & -- & -- & .02 & 2.36 & -- & -- \\
\hline & $04-23-86$ & 19.5 & 34 & 4.8 & 1 & 2.4 & $<.01$ & 2.05 & $<.01$ & -- \\
\hline & $06-26-86$ & 19.0 & 35 & 4.8 & - & 2.3 & $<.01$ & 1.96 & $<.01$ & -- \\
\hline \multirow[t]{7}{*}{$10 Q 025$} & $08-27-85$ & - & 53 & -- & - & 5.1 & .02 & 5.08 & -- & .01 \\
\hline & $09-19-85$ & -- & 60 & -- & -- & 6.2 & .02 & 4.52 & - & $<.01$ \\
\hline & $10-03-85$ & -- & 51 & -- & -- & - & .01 & 5.11 & -- & -- \\
\hline & $03-27-86$ & 20.0 & 70 & 4.5 & $<1$ & 9.8 & .01 & 4.86 & $<.01$ & -- \\
\hline & $04-21-86$ & 19.5 & 65 & 4.5 & $<1$ & 5.1 & $<.01$ & 4.55 & $<.01$ & -- \\
\hline & $05-22-86$ & 20.0 & 66 & 4.5 & -- & 5.0 & $<.01$ & 3.96 & $<.01$ & -- \\
\hline & $06-24-86$ & 19.5 & 70 & 4.6 & -- & 4.9 & $<.01$ & 4.36 & $<.01$ & -- \\
\hline
\end{tabular}


Table 4.--Results of analyses of chemical inorganic constitutents in ground water, 1985-86-Continued

$\left[{ }^{\circ} \mathrm{C}\right.$, degrees Celcius; $\mu \mathrm{S} / \mathrm{cm}$, microsiemens per centimeter; $\mathrm{mg} / \mathrm{L}$ as $\mathrm{CaCO}_{3}$, milligrams per liter as calcium carbonate; $\mathrm{mg} / \mathrm{L}$, milligrams per liter; <, less than detection level; --, not analyzed for]

\begin{tabular}{|c|c|c|c|c|c|c|c|c|c|c|}
\hline $\begin{array}{c}\text { Well } \\
\text { number }\end{array}$ & $\begin{array}{l}\text { Sample } \\
\text { date }\end{array}$ & $\begin{array}{c}\text { Water } \\
\text { tempera- } \\
\text { ture } \\
\left({ }^{\circ} \mathrm{C}\right)\end{array}$ & $\begin{array}{c}\text { Specific } \\
\text { conduct- } \\
\text { ance } \\
(\mu \mathrm{S} / \mathrm{cm})\end{array}$ & $\mathrm{pH}$ & $\begin{array}{l}\text { Alkalinity } \\
\text { as } \mathrm{CaCO}_{3} \\
(\mathrm{mg} / \mathrm{L})\end{array}$ & $\begin{array}{l}\text { Chloride } \\
\text { (mg/L) }\end{array}$ & $\begin{array}{l}\text { Ammonia- } \\
\text { nitrogen } \\
\text { as } N \\
(\mathrm{mg} / \mathrm{L})\end{array}$ & $\begin{array}{l}\text { Nitrate- } \\
\text { nitrogen } \\
\text { as N } \\
\text { (mg/L) }\end{array}$ & $\begin{array}{l}\text { Nitrite- } \\
\text { nitrogen } \\
\text { as N } \\
\text { (mg/L) }\end{array}$ & $\begin{array}{l}\text { O-phos- } \\
\text { phate } \\
\text { as P } \\
\text { (mg/L) }\end{array}$ \\
\hline $10 \mathrm{Q} 026$ & $\begin{array}{l}10-03-85 \\
03-26-86\end{array}$ & $\overline{19.5}$ & $\begin{array}{l}37 \\
45\end{array}$ & $4 . \overline{7}$ & $\overline{1}$ & $\overline{3.2}$ & $\begin{array}{r}0.01 \\
.01\end{array}$ & $\begin{array}{l}2.87 \\
2.88\end{array}$ & $<\overline{0.01}$ & - \\
\hline $10 Q 027$ & $10-03-85$ & - & 43 & - & - & - & .02 & 3.99 & - & - \\
\hline $10 Q 028$ & $\begin{array}{l}08-27-85 \\
09-19-85 \\
10-03-86 \\
03-21-86 \\
04-22-86 \\
05-22-86\end{array}$ & $\begin{array}{l}- \\
\overline{-} \\
\overline{18.0} \\
18.0 \\
19.0\end{array}$ & $\begin{array}{l}45 \\
48 \\
38 \\
52 \\
50 \\
51\end{array}$ & $\begin{array}{r}- \\
- \\
4.6 \\
4.6 \\
4.6\end{array}$ & $\begin{array}{l}- \\
- \\
- \\
1 \\
<1 \\
-\end{array}$ & \begin{tabular}{l|}
3.8 \\
3.5 \\
- \\
3.7 \\
3.5 \\
3.0
\end{tabular} & $\begin{array}{r}.02 \\
.04 \\
<.01 \\
.04 \\
<.01 \\
.05\end{array}$ & $\begin{array}{l}4.00 \\
3.44 \\
3.90 \\
3.13 \\
3.33 \\
3.30\end{array}$ & $\begin{array}{l}- \\
- \\
\overline{<} \\
<.01 \\
<.01 \\
<.01\end{array}$ & $\begin{array}{l}- \\
- \\
-\end{array}$ \\
\hline $10 Q 029$ & $\begin{array}{l}10-03-85 \\
05-21-86\end{array}$ & $\overline{19.5}$ & $\begin{array}{l}38 \\
47\end{array}$ & $4 . \overline{6}$ & - & $\overline{3.3}$ & $\begin{array}{r}.02 \\
<.01\end{array}$ & $\begin{array}{l}3.13 \\
2.30\end{array}$ & $\overline{<}-01$ & - \\
\hline $10 Q 030$ & $\begin{array}{l}08-27-85 \\
09-19-85 \\
10-03-85 \\
03-27-86 \\
04-21-86 \\
05-20-86 \\
06-24-86 \\
03-26-86 \\
05-21-86\end{array}$ & $\begin{array}{c}- \\
- \\
- \\
20.0 \\
19.5 \\
20.0 \\
19.5 \\
20.0 \\
19.5\end{array}$ & $\begin{array}{l}47 \\
50 \\
40 \\
57 \\
52 \\
53 \\
55 \\
40 \\
36\end{array}$ & $\begin{array}{r}- \\
- \\
- \\
4.6 \\
4.5 \\
4.5 \\
4.6 \\
4.9 \\
4.8\end{array}$ & $\begin{array}{l}- \\
-- \\
- \\
1 \\
1 \\
-- \\
-- \\
1 \\
-\end{array}$ & $\begin{array}{l}4.1 \\
5.0 \\
- \\
4.4 \\
4.1 \\
3.5 \\
3.7 \\
3.0 \\
2.4\end{array}$ & $\begin{array}{r}.02 \\
.03 \\
.02 \\
<.01 \\
<.01 \\
<.01 \\
<.01 \\
<.01 \\
<.01\end{array}$ & $\begin{array}{l}3.88 \\
3.61 \\
3.76 \\
3.64 \\
3.50 \\
2.98 \\
3.13 \\
2.68 \\
1.93\end{array}$ & $\begin{array}{l}- \\
- \\
- \\
<.01 \\
<.01 \\
<.01 \\
<.01 \\
<.01 \\
<.01\end{array}$ & $\begin{array}{r}0.01 \\
.01 \\
- \\
- \\
- \\
- \\
- \\
- \\
-\end{array}$ \\
\hline $10 Q 023$ & $\begin{array}{l}08-27-85 \\
10-03-85\end{array}$ & - & $\begin{array}{l}26 \\
24\end{array}$ & - & - & $\begin{array}{l}3.9 \\
--\end{array}$ & $\begin{array}{l}.04 \\
.02\end{array}$ & $\begin{array}{l}1.31 \\
1.50\end{array}$ & - & $\begin{array}{r}<.01 \\
-\end{array}$ \\
\hline $10 Q 024$ & $\begin{array}{l}08-27-85 \\
10-03-85 \\
05-21-86\end{array}$ & $\frac{-}{20.5}$ & $\begin{array}{l}34 \\
34 \\
43\end{array}$ & $\overline{-}$ & $\begin{array}{l}- \\
-\end{array}$ & $\begin{array}{l}2.8 \\
- \\
2.5\end{array}$ & $\begin{array}{r}.02 \\
.02 \\
<.01\end{array}$ & $\begin{array}{l}3.23 \\
3.20 \\
2.49\end{array}$ & $\begin{array}{l}- \\
- \\
<.01\end{array}$ & $\begin{array}{l}- \\
- \\
-\end{array}$ \\
\hline $10 Q 031$ & $09-19-85$ & - & 43 & -- & -- & 3.9 & .01 & 2.49 & - & .01 \\
\hline $10 Q 032$ & $\begin{array}{l}09-19-85 \\
03-27-86 \\
04-22-86 \\
06-27-86\end{array}$ & $\begin{array}{l}- \\
21.5 \\
19.5 \\
19.5\end{array}$ & $\begin{array}{l}34 \\
36 \\
34 \\
34\end{array}$ & $\begin{array}{l}-- \\
4.9 \\
4.8 \\
4.9\end{array}$ & $\begin{array}{r}-- \\
<1 \\
-\end{array}$ & $\begin{array}{l}3.6 \\
2.4 \\
2.5 \\
2.3\end{array}$ & $\begin{array}{r}.04 \\
<.01 \\
<.01 \\
<.01\end{array}$ & $\begin{array}{l}1.90 \\
2.28 \\
2.14 \\
2.02\end{array}$ & $\begin{array}{l}- \\
<.01 \\
<.01 \\
<.01\end{array}$ & $\begin{array}{r}.01 \\
- \\
- \\
-\end{array}$ \\
\hline $10 Q 033$ & $\begin{array}{l}03-27-86 \\
05-22-86\end{array}$ & $\begin{array}{l}19.5 \\
19.5\end{array}$ & $\begin{array}{l}54 \\
52\end{array}$ & $\begin{array}{l}4.7 \\
4.6\end{array}$ & - & $\begin{array}{l}4.7 \\
3.7\end{array}$ & $\begin{array}{r}.02 \\
<.01\end{array}$ & $\begin{array}{l}3.40 \\
2.34\end{array}$ & $\begin{array}{l}<.01 \\
<.01\end{array}$ & - \\
\hline 100034 & $09-19-85$ & - & 35 & -- & - & 3.3 & .05 & 2.73 & - & .01 \\
\hline 100035 & $\begin{array}{l}10-03-85 \\
06-25-86\end{array}$ & $\overline{19.5}$ & $\begin{array}{l}40 \\
50\end{array}$ & $4 . \overline{7}$ & - & $-\overline{4.2}$ & $\begin{array}{r}.02 \\
<.01\end{array}$ & $\begin{array}{l}1.10 \\
3.53\end{array}$ & $\overline{<}-01$ & - \\
\hline
\end{tabular}


Table 4.--Results of analyses of chemical inorganic constitutents in ground water, 1985-86-Continued

[ ${ }^{\circ} \mathrm{C}$, degrees Celcius; $\mu \mathrm{S} / \mathrm{cm}$, microsiemens per centimeter; $\mathrm{mg} / \mathrm{L}$ as $\mathrm{CaCO}_{3}$, milligrams per liter as calcium carbonate; $\mathrm{mg} / \mathrm{L}$, milligrams per liter; <, less than detection level; --, not analyzed for]

\begin{tabular}{|c|c|c|c|c|c|c|c|c|c|c|}
\hline $\begin{array}{c}\text { Well } \\
\text { number }\end{array}$ & $\begin{array}{c}\text { Sample } \\
\text { date }\end{array}$ & $\begin{array}{c}\text { Water } \\
\text { tempera- } \\
\text { ture } \\
\left({ }^{\circ} \mathrm{C}\right)\end{array}$ & $\begin{array}{c}\text { Specific } \\
\text { conduct- } \\
\text { ance } \\
(\mu \mathrm{S} / \mathrm{cm})\end{array}$ & $\mathrm{pH}$ & $\begin{array}{l}\text { Alkalinity } \\
\text { as } \mathrm{CaCO}_{3} \\
(\mathrm{mg} / \mathrm{L})\end{array}$ & $\begin{array}{l}\text { Chloride } \\
\text { (mg/L) }\end{array}$ & $\begin{array}{l}\text { Ammonia- } \\
\text { nitrogen } \\
\text { as } N \\
\text { (mg/L) }\end{array}$ & $\begin{array}{l}\text { Nitrate- } \\
\text { nitrogen } \\
\text { as N } \\
\text { (mg/L) }\end{array}$ & $\begin{array}{l}\text { Nitrite- } \\
\text { nitrogen } \\
\text { as } \mathrm{N} \\
\text { (mg/L) }\end{array}$ & $\begin{array}{l}\text { O-phos- } \\
\text { phate } \\
\text { as P } \\
\text { (mg/L) }\end{array}$ \\
\hline 10Q036 & $\begin{array}{l}05-21-86 \\
06-25-86\end{array}$ & $\begin{array}{l}19.5 \\
20.0\end{array}$ & $\begin{array}{l}52 \\
51\end{array}$ & $\begin{array}{l}4.6 \\
4.7\end{array}$ & - & $\begin{array}{l}3.3 \\
3.2\end{array}$ & $\begin{array}{r}<0.01 \\
<.01\end{array}$ & $\begin{array}{l}2.88 \\
3.43\end{array}$ & $\begin{array}{r}<0.01 \\
<.01\end{array}$ & - \\
\hline $10 Q 037$ & $\begin{array}{l}09-19-85 \\
10-03-85 \\
03-28-86 \\
05-21-86\end{array}$ & $\begin{array}{c}- \\
- \\
20.5 \\
20.5\end{array}$ & $\begin{array}{l}24 \\
20 \\
23 \\
21\end{array}$ & $\begin{array}{r}- \\
- \\
5.1 \\
5.1\end{array}$ & $\begin{array}{l}- \\
- \\
-\end{array}$ & $\begin{array}{l}2.8 \\
- \\
2.1 \\
1.4\end{array}$ & $\begin{array}{r}.05 \\
.02 \\
.02 \\
<.01\end{array}$ & $\begin{array}{r}0.07 \\
1.10 \\
1.09 \\
.54\end{array}$ & $\begin{array}{l}- \\
- \\
- \\
<.01\end{array}$ & $\begin{array}{r}.01 \\
- \\
- \\
-\end{array}$ \\
\hline $10 Q 039$ & $\begin{array}{l}08-27-85 \\
09-19-85 \\
10-03-85 \\
03-20-86 \\
04-22-86 \\
05-22-86\end{array}$ & $\begin{array}{c}-- \\
-- \\
- \\
18.0 \\
18.5 \\
18.5\end{array}$ & $\begin{array}{l}30 \\
30 \\
27 \\
34 \\
36 \\
36\end{array}$ & $\begin{array}{r}-. \\
- \\
-\overline{6} \\
4.7 \\
4.7\end{array}$ & $\begin{array}{r}-- \\
- \\
<1 \\
1 \\
-\end{array}$ & $\begin{array}{l}3.5 \\
3.4 \\
- \\
3.0 \\
2.9 \\
2.6\end{array}$ & $\begin{array}{r}.03 \\
.03 \\
<.01 \\
.02 \\
<.01 \\
<.01\end{array}$ & $\begin{array}{l}1.82 \\
1.71 \\
1.81 \\
1.46 \\
1.84 \\
1.51\end{array}$ & $\begin{array}{l}- \\
-- \\
- \\
<.01 \\
<.01 \\
<.01\end{array}$ & $\begin{array}{r}<.01 \\
.02 \\
- \\
- \\
- \\
-\end{array}$ \\
\hline $10 Q 040$ & $\begin{array}{l}09-19-85 \\
10-03-85 \\
03-26-86 \\
04-22-86 \\
06-27-86\end{array}$ & $\begin{array}{l}- \\
- \\
20.0 \\
19.5 \\
19.5\end{array}$ & $\begin{array}{l}19 \\
16 \\
18 \\
18 \\
17\end{array}$ & $\begin{array}{r}-- \\
5.0 \\
4.9 \\
4.9\end{array}$ & $\begin{array}{l}- \\
- \\
1 \\
-\end{array}$ & $\begin{array}{l}5.2 \\
1.7 \\
1.8 \\
1.9\end{array}$ & $\begin{array}{l}.03 \\
<.01 \\
<.01 \\
<.01 \\
<.01\end{array}$ & $\begin{array}{l}.35 \\
.70 \\
.41 \\
.34 \\
.20\end{array}$ & $\begin{array}{l}- \\
- \\
<.01 \\
<.01 \\
<.01\end{array}$ & $\begin{array}{l}.02 \\
- \\
- \\
- \\
-\end{array}$ \\
\hline 100041 & $\begin{array}{l}10-03-85 \\
05-21-86\end{array}$ & $\overline{19.5}$ & $\begin{array}{l}19 \\
24\end{array}$ & $5 . \overline{0}$ & - & $\overline{1.8}$ & $\begin{array}{r}.02 \\
<.01\end{array}$ & $\begin{array}{l}.94 \\
.64\end{array}$ & $\begin{array}{l}-- \\
<.01\end{array}$ & $\begin{array}{l}-- \\
--\end{array}$ \\
\hline 100044 & $05-21-86$ & 20.0 & 38 & 4.7 & - & 2.6 & $<.01$ & 2.26 & $<.01$ & - \\
\hline 100046 & $04-23-86$ & 19.0 & 20 & 5.1 & 2 & 1.6 & $<.01$ & 1.02 & $<.01$ & - \\
\hline $10 Q 048$ & $\begin{array}{l}03-20-86 \\
04-23-86 \\
05-22-86 \\
06-25-86\end{array}$ & $\begin{array}{l}19.5 \\
20.0 \\
20.0 \\
19.5\end{array}$ & $\begin{array}{l}32 \\
32 \\
32 \\
32\end{array}$ & $\begin{array}{l}4.8 \\
4.9 \\
4.8 \\
4.9\end{array}$ & $\begin{array}{l}1 \\
2 \\
- \\
-\end{array}$ & $\begin{array}{l}3.3 \\
2.5 \\
2.8 \\
2.0\end{array}$ & $\begin{array}{r}.04 \\
<.01 \\
<.01 \\
<.01\end{array}$ & $\begin{array}{l}2.29 \\
2.01 \\
1.85 \\
1.86\end{array}$ & $\begin{array}{l}<.01 \\
<.01 \\
<.01 \\
<.01\end{array}$ & $\begin{array}{l}- \\
- \\
- \\
-\end{array}$ \\
\hline 100049 & $\begin{array}{l}05-20-86 \\
05-25-86\end{array}$ & $\begin{array}{l}18.5 \\
18.0\end{array}$ & $\begin{array}{l}50 \\
50\end{array}$ & $\begin{array}{l}4.6 \\
4.7\end{array}$ & - & $\begin{array}{l}2.8 \\
2.5\end{array}$ & $\begin{array}{l}<.01 \\
<.01\end{array}$ & $\begin{array}{l}3.32 \\
2.90\end{array}$ & $\begin{array}{l}<.01 \\
<.01\end{array}$ & $\begin{array}{l}- \\
-\end{array}$ \\
\hline $10 Q 050$ & $05-20-86$ & 20.0 & 47 & 4.7 & - & 3.0 & $<.01$ & 3.21 & $<.01$ & -- \\
\hline $10 Q 051$ & $\begin{array}{l}03-28-86 \\
04-22-86\end{array}$ & $\begin{array}{l}18.5 \\
18.5\end{array}$ & $\begin{array}{l}43 \\
43\end{array}$ & $\begin{array}{l}4.9 \\
4.9\end{array}$ & $\begin{array}{l}1 \\
1\end{array}$ & $\begin{array}{l}3.1 \\
2.5\end{array}$ & $\begin{array}{l}.03 \\
.01\end{array}$ & $\begin{array}{l}2.88 \\
2.74\end{array}$ & $\begin{array}{l}<.01 \\
<.01\end{array}$ & $\begin{array}{l}- \\
-\end{array}$ \\
\hline $10 Q 052$ & $\begin{array}{l}03-26-86 \\
04-22-86 \\
05-22-86\end{array}$ & $\begin{array}{l}19.0 \\
19.0 \\
19.0\end{array}$ & $\begin{array}{l}48 \\
48 \\
46\end{array}$ & $\begin{array}{l}4.8 \\
4.8 \\
4.8\end{array}$ & $\begin{array}{l}1 \\
1 \\
-\end{array}$ & $\begin{array}{l}3.0 \\
2.8 \\
3.1\end{array}$ & $\begin{array}{r}.02 \\
<.01 \\
<.01\end{array}$ & $\begin{array}{l}3.26 \\
3.22 \\
3.08\end{array}$ & $\begin{array}{l}<.01 \\
<.01 \\
<.01\end{array}$ & $\begin{array}{l}- \\
- \\
-\end{array}$ \\
\hline $10 Q 054$ & $06-28-86$ & 17.5 & 33 & 4.8 & - & 2.1 & $<.01$ & 1.63 & $<.01$ & - \\
\hline
\end{tabular}


Table 4.--Results of analyses of chemical inorganic constitutents in ground water, 1985-86-Continued

$\left[{ }^{\circ} \mathrm{C}\right.$, degrees Celcius; $\mu \mathrm{S} / \mathrm{cm}$, microsiemens per centimeter; $\mathrm{mg} / \mathrm{L}$ as $\mathrm{CaCO}_{3}$, milligrams per liter as calcium carbonate; $\mathrm{mg} / \mathrm{L}$, milligrams per liter; <, less than detection level; --, not analyzed for]

\begin{tabular}{|c|c|c|c|c|c|c|c|c|c|c|}
\hline $\begin{array}{c}\text { Well } \\
\text { number }\end{array}$ & $\begin{array}{l}\text { Sample } \\
\text { date }\end{array}$ & $\begin{array}{c}\text { Water } \\
\text { tempera- } \\
\text { ture } \\
\left({ }^{\circ} \mathrm{C}\right)\end{array}$ & $\begin{array}{c}\text { Specific } \\
\text { conduct- } \\
\text { ance } \\
(\mu \mathrm{S} / \mathrm{cm})\end{array}$ & $\mathrm{pH}$ & $\begin{array}{l}\text { Alkalinity } \\
\text { as } \mathrm{CaCO}_{3} \\
(\mathrm{mg} / \mathrm{L})\end{array}$ & $\begin{array}{c}\text { Chloride } \\
\text { (mg/L) }\end{array}$ & $\begin{array}{l}\text { Ammonia- } \\
\text { nitrogen } \\
\text { as } N \\
(\mathrm{mg} / \mathrm{L})\end{array}$ & $\begin{array}{c}\text { Nitrate- } \\
\text { nitrogen } \\
\text { as N } \\
\text { (mg/L) }\end{array}$ & $\begin{array}{l}\text { Nitrite- } \\
\text { nitrogen } \\
\text { as } N \\
(\mathrm{mg} / \mathrm{L})\end{array}$ & $\begin{array}{c}\text { O-phos- } \\
\text { phate } \\
\text { as } P \\
\text { (mg/L) }\end{array}$ \\
\hline $10 Q 055$ & $\begin{array}{l}04-23-86 \\
05-22-86 \\
06-26-86\end{array}$ & $\begin{array}{l}18.0 \\
17.5 \\
17.5\end{array}$ & $\begin{array}{l}37 \\
37 \\
42\end{array}$ & $\begin{array}{l}5.0 \\
5.0 \\
5.0\end{array}$ & $\begin{array}{l}5 \\
- \\
-\end{array}$ & $\begin{array}{l}2.4 \\
2.1 \\
2.1\end{array}$ & $\begin{array}{l}<0.01 \\
<.01 \\
<.01\end{array}$ & $\begin{array}{l}0.14 \\
<.01 \\
<.01\end{array}$ & $\begin{array}{l}<0.01 \\
<.01 \\
<.01\end{array}$ & $\begin{array}{l}- \\
-\end{array}$ \\
\hline 100056 & $06-26-86$ & 18.5 & 25 & 5.4 & 6 & 1.7 & $<.01$ & $<.01$ & $<.01$ & - \\
\hline 10P057 & $06-25-86$ & 19.0 & 29 & 5.0 & 3 & 2.1 & $<.01$ & .57 & $<.01$ & - \\
\hline 10P058 & $06-25-86$ & 19.0 & 22 & 5.0 & 1 & 1.9 & $<.01$ & .72 & $<.01$ & - \\
\hline 10P059 & $06-25-86$ & 18.5 & 24 & 5.0 & 1 & 1.9 & $<.01$ & .95 & $<.01$ & - \\
\hline $10 \mathrm{P} 060$ & $06-26-86$ & 20.0 & 43 & 5.6 & - & 3.4 & $<.01$ & $<.01$ & $<.01$ & - \\
\hline 10P061 & $06-26-86$ & 18.5 & 22 & 5.0 & 1 & 2.0 & $<.01$ & .38 & $<.01$ & - \\
\hline 10P062 & $06-25-86$ & 19.5 & 22 & 5.3 & 2 & 1.3 & $<.01$ & .83 & $<.01$ & - \\
\hline 10P064 & $06-25-86$ & 20.0 & 32 & 5.4 & 3 & 2.0 & .01 & .67 & $<.01$ & - \\
\hline $10 Q 065$ & $06-25-86$ & 19.5 & 40 & 4.9 & - & 2.7 & $<.01$ & 2.21 & $<.01$ & - \\
\hline 100066 & $06-24-86$ & 20.0 & 43 & 5.2 & 1 & 2.8 & $<.01$ & 1.90 & $<.01$ & - \\
\hline 100067 & $06-24-86$ & 19.5 & 54 & 4.6 & - & 2.0 & .09 & 1.74 & $<.01$ & - \\
\hline $10 Q 070$ & $\begin{array}{l}03-19-86 \\
04-21-86 \\
05-20-86 \\
03-20-86 \\
04-21-86 \\
05-20-86\end{array}$ & $\begin{array}{l}20.0 \\
20.0 \\
20.5 \\
19.0 \\
20.0 \\
20.5\end{array}$ & $\begin{array}{l}53 \\
60 \\
50 \\
44 \\
45 \\
45\end{array}$ & $\begin{array}{l}5.4 \\
5.3 \\
5.2 \\
4.8 \\
4.9 \\
4.8\end{array}$ & $\begin{array}{l}4 \\
4 \\
- \\
1 \\
1 \\
-\end{array}$ & $\begin{array}{l}3.1 \\
4.6 \\
4.7 \\
2.9 \\
3.2 \\
2.9\end{array}$ & $\begin{array}{r}.04 \\
<.01 \\
.28 \\
.04 \\
<.01 \\
<.01\end{array}$ & $\begin{array}{l}3.13 \\
3.10 \\
2.60 \\
2.84 \\
2.82 \\
2.52\end{array}$ & $\begin{array}{l}<.01 \\
<.01 \\
<.01 \\
<.01 \\
<.01 \\
<.01\end{array}$ & $\begin{array}{l}- \\
- \\
- \\
- \\
-\end{array}$ \\
\hline $10 Q 072$ & $\begin{array}{l}08-27-85 \\
03-20-86 \\
04-21-86 \\
05-20-86\end{array}$ & $\begin{array}{l}-\overline{19.0} \\
19.5 \\
20.0\end{array}$ & $\begin{array}{l}56 \\
53 \\
58 \\
52\end{array}$ & $\begin{array}{l}-- \\
4.5 \\
4.6 \\
4.6\end{array}$ & $\begin{array}{r}- \\
<1 \\
1 \\
-\end{array}$ & $\begin{array}{l}3.3 \\
3.9 \\
3.7 \\
3.3\end{array}$ & $\begin{array}{r}.02 \\
.03 \\
<.01 \\
<.01\end{array}$ & $\begin{array}{l}3.21 \\
3.34 \\
3.34 \\
2.47\end{array}$ & $\begin{array}{l}- \\
- \\
<.01 \\
<.01\end{array}$ & $\begin{array}{r}.01 \\
- \\
- \\
-\end{array}$ \\
\hline 100073 & $06-26-86$ & 18.0 & 25 & 4.9 & $<1$ & - & - & - & - & - \\
\hline $10 Q 077$ & $06-26-86$ & 18.5 & 50 & 5.0 & - & 2.3 & $<.01$ & 2.26 & $<.01$ & - \\
\hline $10 Q 079$ & $06-24-86$ & 19.5 & 64 & 4.6 & - & 4.0 & $<.01$ & 4.30 & $<.01$ & - \\
\hline $10 Q 080$ & $06-24-86$ & 18.0 & 43 & 5.1 & 1 & 3.6 & $<.01$ & 2.15 & $<.01$ & - \\
\hline $10 Q 081$ & $06-24-86$ & 18.5 & 45 & 4.7 & - & 2.9 & $<.01$ & 1.26 & $<.01$ & - \\
\hline $10 Q 082$ & $06-24-86$ & 19.5 & 46 & 4.8 & - & 4.0 & $<.01$ & 3.00 & $<.01$ & - \\
\hline
\end{tabular}

